Portland State University

PDXScholar

Spring 5-5-2014

\title{
Assessing Hydrologic and Water Quality Sensitivities to Precipitation Changes, Urban Growth and Land Management Using SWAT
}

Alexander Michael Psaris

Portland State University

Follow this and additional works at: https://pdxscholar.library.pdx.edu/open_access_etds

Part of the Water Resource Management Commons

Let us know how access to this document benefits you.

\section{Recommended Citation}

Psaris, Alexander Michael, "Assessing Hydrologic and Water Quality Sensitivities to Precipitation Changes, Urban Growth and Land Management Using SWAT" (2014). Dissertations and Theses. Paper 1783.

https://doi.org/10.15760/etd.1782

This Thesis is brought to you for free and open access. It has been accepted for inclusion in Dissertations and Theses by an authorized administrator of PDXScholar. Please contact us if we can make this document more accessible: pdxscholar@pdx.edu. 
Assessing Hydrologic and Water Quality Sensitivities to Precipitation Changes, Urban

Growth and Land Management Using SWAT

by

Alexander Michael Psaris

A thesis submitted in partial fulfillment of the requirements for the degree of

\author{
Master of Science \\ in \\ Geography
}

Thesis Committee:

Heejun Chang, Chair

Eugene Foster

Martin Lafrenz

Portland State University

2014 
(C) 2014 Alexander Michael Psaris 


\begin{abstract}
Precipitation changes and urban growth are two factors altering the state of water quality. Changes in precipitation will alter the amount and timing of flows, and the corresponding sediment and nutrient dynamics. Meanwhile, densification associated with urban growth will create more impervious surfaces which will alter sediment and nutrient loadings. Land and water managers often rely on models to develop possible future scenarios and devise management responses to these projected changes. We use the Soil and Water Assessment Tool (SWAT) to assess the sensitivities of stream flow, sediment, and nutrient loads in two urbanizing watersheds in Northwest Oregon, USA to various climate and urbanization scenarios. We evaluate the spatial patterns climate change and urban growth will have on water, sediment and nutrient yields. We also identify critical source areas (CSAs) and investigate how implementation of vegetative filter strips (VFS) could ameliorate the effects of these changes. Our findings suggest that: 1) Water yield is tightly coupled to precipitation. 2) Large increases in winter and spring precipitation provide enough sub-surface storage to increase summertime water yields despite a moderate decrease in summer precipitation. 3) Expansion of urban areas increases surface runoff and has mixed effects on sediment and nutrients. 4) Implementation of VFS reduces pollutant loads helping overall watershed health. This research demonstrates the usefulness of SWAT in facilitating informed land and water management decisions.
\end{abstract}




\section{Acknowledgements}

This thesis would not have been possible without the help and support of my family, friends, classmates, committee members and knowledgeable professionals. I'd like to thank Heejun Chang for his guidance throughout these past three years. I'd also like to thank Jim Almendinger who relentlessly offers advice to SWAT modelers worldwide through the SWAT-User google group. I and many others have learned a great deal about SWAT through his eloquent explanations. I'd like to thank Martin Lafrenz for lending his expertise in the area of sediment and erosion processes. I'd like to thank my lab mate and collaborator on the SESAME grant Wes Hoyer who is an intelligent and pleasant person to work with. I'd like to thank Gene Foster for his willingness to lend support and provide data from the DEQ. I'd like to thank Raj Kapour from Clean Water Services for offering his expertise on the Tualatin River Basin, and providing waste water treatment plant data. Finally, I'd like to thank the professors and students of the Geography Department who have helped guide and support me throughout my graduate career. 


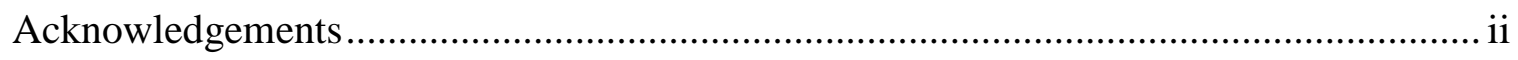

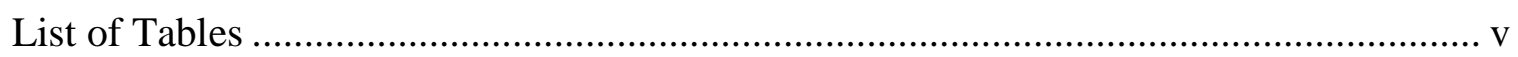

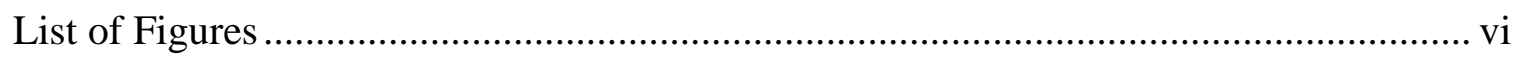

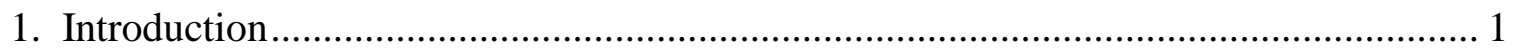

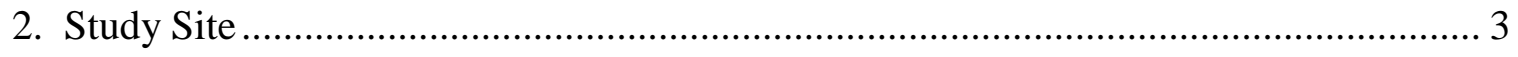

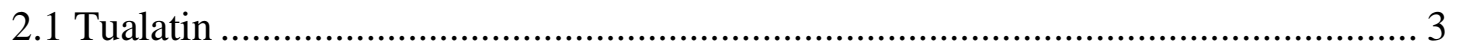

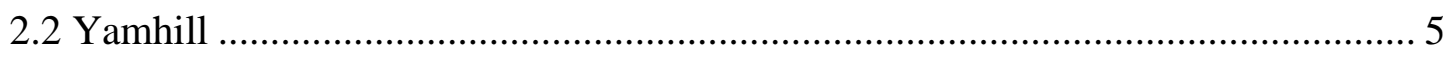

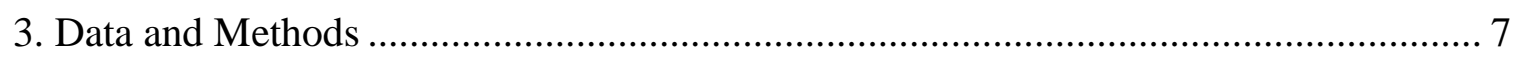

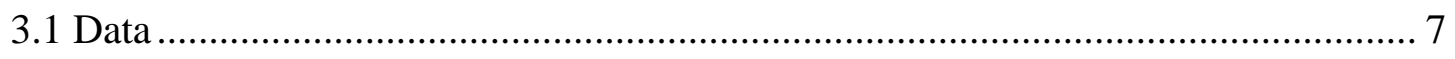

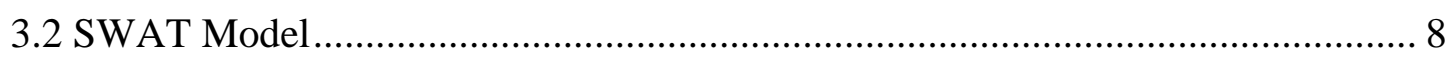

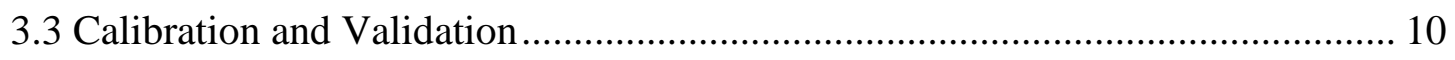

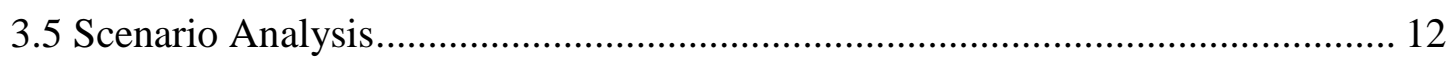

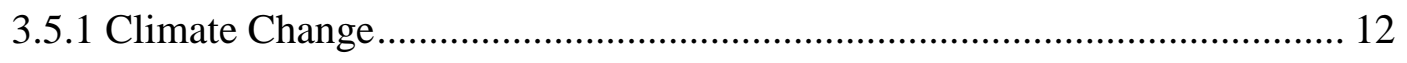

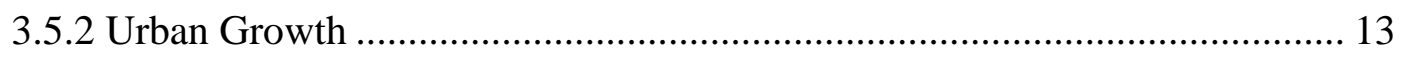

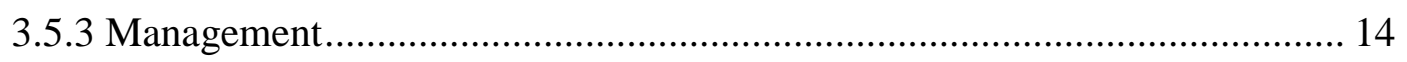

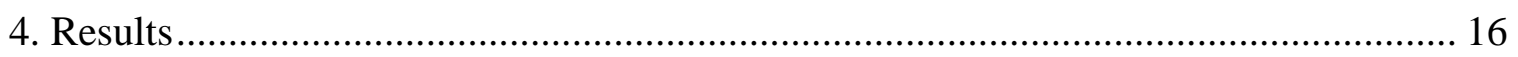

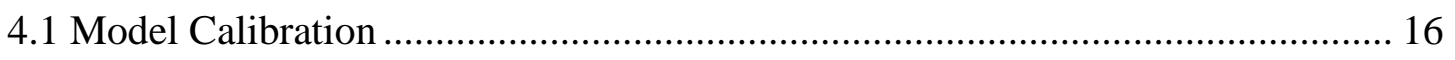

4.2 Future Changes Under Climate and Land Cover Change Scenarios ................... 18

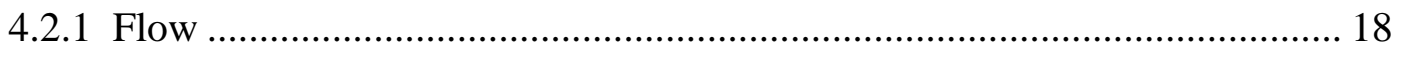

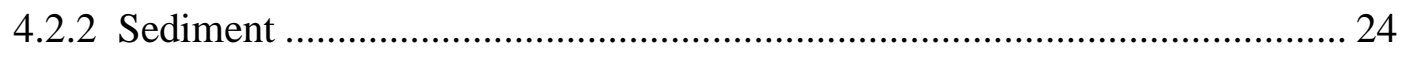

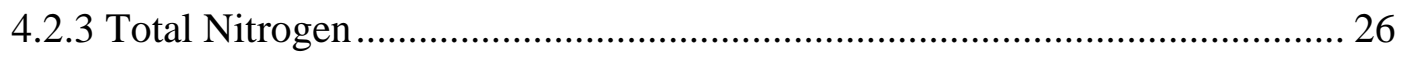

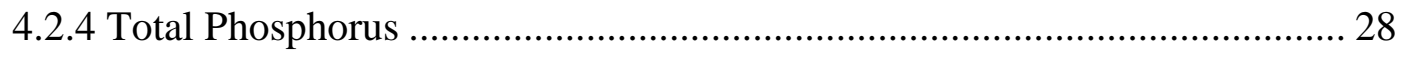

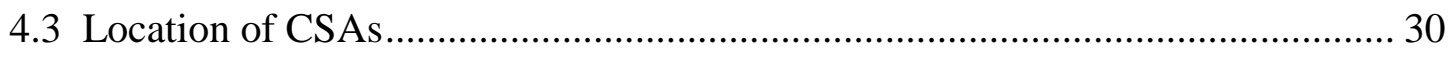

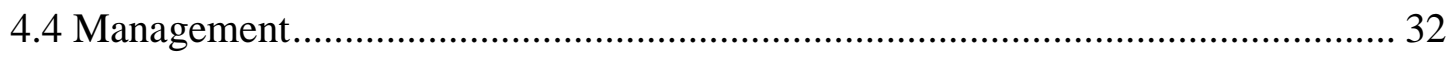

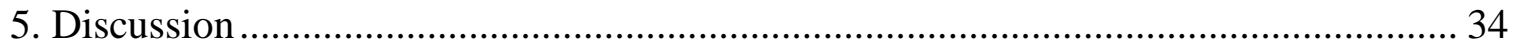

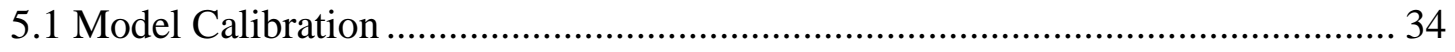


5.2 Spatial Patterns of Flow, Sediment, and Nutrients

5.3 Future Changes and Adaptive Management ................................................... 38

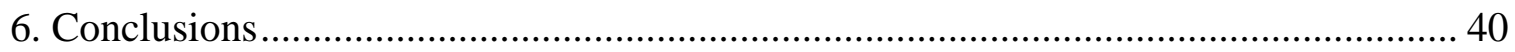

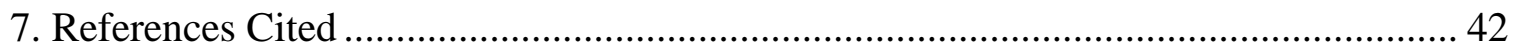

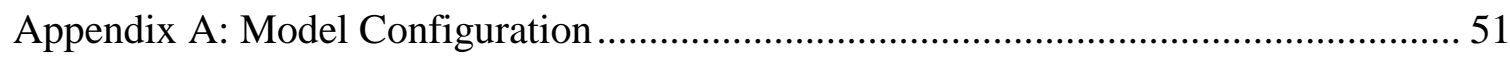

Appendix B: Sensitivity Analysis, Calibration, and Validation .................................. 54

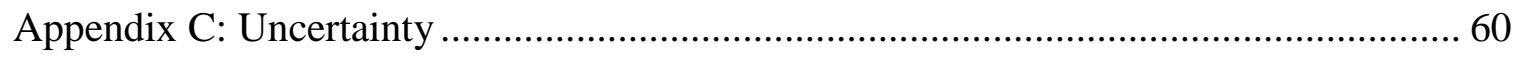

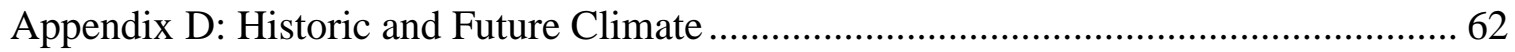

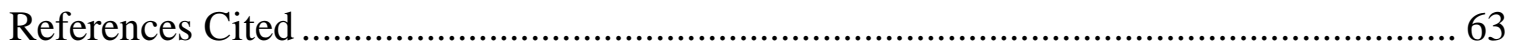




\section{List of Tables}

Table 1: SWAT model input data and their sources used in the current study................. 7

Table 2: Gages used for model evaluation. $\mathrm{F}=$ Flow, TSS $=$ Total Suspended Solids, TN $=$ Total Nitrogen, $\mathrm{TP}=$ Total Phosphorus. Calibration gages are italicized.............. 12

Table 3: List of final calibrated parameters for Tualatin and Yamhill sub-basins. ......... 16

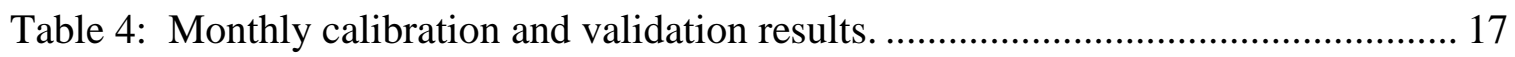

Table 5: Percent change in annual and seasonal precipitation and flow for Tualatin and Yamhill under climate change and urban growth scenarios. ................................ 22

Table 6: Percent change in annual and seasonal sediment loadings ............................ 25

Table 7: Percent change in annual and seasonal TN loadings.................................... 27

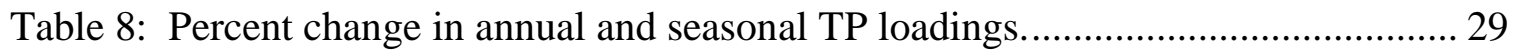

Table 9: Comparison of top 5\% sub-basins before and after VFS applied..................... 33 


\section{List of Figures}

Figure 1: Map of the Tualatin and Yamhill River basins. Gage numbers are referenced

in Table 1 .

Figure 2: Elevation, soils, land use, and precipitation datasets used in the SWAT model.8

Figure 3: Area weighted changes in precipitation and temperature for each of the three climate scenarios split by season (Winter=DJF, Summer=JJA)

Figure 4: Changes in precipitation, air temperature, and flow for the high urban scenario for Tualatin: low (a), medium (b), and high (a) climate scenarios. Yamhill: low (d), medium (e), high (f) climate scenarios.

Figure 5: Percent change in average annual water yield by sub-basin. 23

Figure 6: Percent change in average summer water yield.

Figure 7: Percent change in annual average sediment yields. 26

Figure 8: Percent change in annual average $\mathrm{TN}$ yield. 28

Figure 9: Percent change in annual average TP yields. 30

Figure 10: Shifts in hotspots due to climate change and urbanization. 32

Figure 11: Spatial patterns of predicted flow, sediment, total nitrogen, and total phosphorus. 36 


\section{Introduction}

Precipitation changes and urban growth are two major factors altering watershed dynamics worldwide (Vorosmarty et al. 2000, Whitehead et al. 2009). Precipitation drives the amount and timing of river flows (Chang et al. 2001; Choi 2008; Franzyk \& Chang 2009; Tu 2009; Praskievicz and Chang 2011), which in turn drive sediment and nutrient loads (Randall and Mulla 2001; Tong and Chen 2002; Chang 2004; Tang et al 2005; Atasoy et al 2006). Urban growth increases impervious surface areas causing flashier storm responses. The increased overland flows carry nutrients more rapidly to streams and instream nutrient removal is negatively correlated to urbanization (Paul and Meyer 2001; Meyer et al. 2005; Walsch et al. 2005).

Given these realities, land and water managers are interested in possible solutions to ameliorate the negative changes to water quality. One such possibility is the addition of vegetative filter strips. These are lands set aside to intercept runoff from crop lands, range lands or other land uses before the water enters streams. These areas consist of natural vegetation that filters sediment and nutrients from overland flows (Abu-Zreig 2001; Abu-Zreig et al. 2004). While this does not directly address urban pollutants, this could serve to improve downstream water quality, helping improve overall watershed health.

The Soil and Water Assessment Tool (SWAT) is a semi-distributed watershed model developed by the USDA's Agricultural Research Service to address the issue of 
non-point source pollution (Arnold et al. 2011). It has the capacity to model large areas with diverse land uses, and includes algorithms to test the effects of best management techniques, including vegetative filter strips. Niraula et al (2013) used SWAT to identify critical source areas of pollutants in their study basin. Gu and Sahu (2009) used SWAT to locate high impact sub-basins and measure nutrient reductions after installing filterstrips. Lam et al (2011) assess both the water quality as well as economic impacts of installing filter strips. In this study we investigate the following research questions.

(1) How do water, sediment and nutrient yields change annually and seasonally under precipitation changes and urban growth scenarios?

(2) What are the locations of CSAs and will these CSAs shift in the future under the combined scenarios of climate change and urban development?

(3) What effect does implementation of VFS have on sediment and nutrient yields? 


\section{Study Site}

\subsection{Tualatin}

The $1,829 \mathrm{~km}^{2}$ Tualatin River Basin mostly shares the boundaries of Washington County in Northwestern Oregon (Fig. 1). The basin is bordered by the Coast Range to the west, Tualatin Mountains (West Hills) to the north and east, and the Chehalem Mountains to the south. With the exception of its headwaters that originate in the Coast Range, the Tualatin River is a low-gradient, meandering river that travels $130 \mathrm{~km}$ east, before emptying into the Willamette River. Elevation in the basin ranges from a high of 1,057 $\mathrm{m}$ to a low of $17 \mathrm{~m}$ at the river's mouth, and has a mean elevation of $195 \mathrm{~m}$. Soils in the basin formed from weathering of the Columbia River Basalts, and deposition of the Willamette Silts by the Missoula Floods during the late Pleistocene. The region has a modified marine climate, dominated by cool wet winters, and warm dry summers. In upper elevations, annual precipitation ranges from 1,330 to $3,280 \mathrm{~mm}$, and average daily temperatures range from 4 to $27^{\circ} \mathrm{C}$ in the summer and -16 to $12^{\circ} \mathrm{C}$ in the winter. In the valley, annual precipitation ranges from 740 to $1,850 \mathrm{~mm}$, and average daily temperatures range from 10 to $31^{\circ} \mathrm{C}$ in the summer, and -10 to $15^{\circ} \mathrm{C}$ in the winter (Abazoglou 2013).

Stream flow is largely rain dominated with peak flows occurring throughout January, and low flows occurring during July. The basin has a runoff ratio of 0.64 based on 16 years of flow records. Two large dams alter the hydrology of the basin. Scoggins 
Dam on Scoggins Creek provides supplemental flows of around $5.97 \mathrm{cms}$ in the summertime as well as recreational opportunities for local residents. Barney reservoir provides additional flows of around $0.4 \mathrm{cms}$ as an inter-basin water transfer from the Trask River to the upstream portion of the Tualatin. Clean Water Services (CWS) operates four waste-water treatment plants (WWTPs) located along the main stem of the Tualatin River. The two downstream plants, Durham and Rock Creek, process the majority of effluent, while the two upstream plants, Hillsboro and Forest Grove, maintain reserve capacity for anticipated population growth.

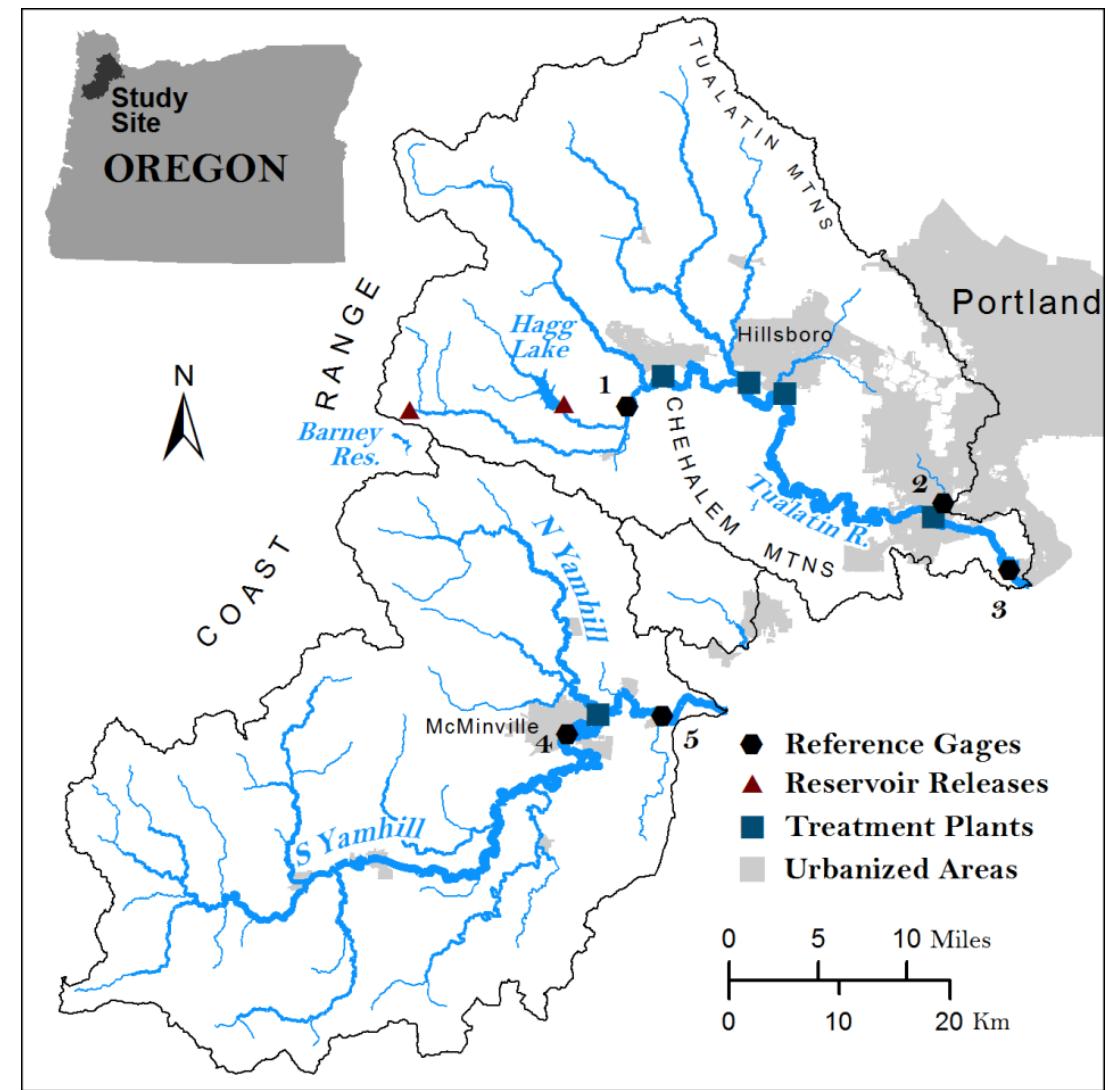

Figure 1: Map of the Tualatin and Yamhill River basins. Gage numbers are referenced in Table 1.

Agricultural land dominates the basin. Approximately $49 \%$ of land in the basin is cultivated, while forested lands comprise $23 \%$, and $14 \%$ has been developed. The 
majority of the basin (93\%) is privately owned. Of public lands, $5 \%$ is owned by the State of Oregon and 2\% is owned by the Bureau of Land Management (ODEQ 2001).

Due to agriculture, timber harvesting, and rapid urbanization in the mid- $20^{\text {th }}$ century, the basin suffered from poor water quality. In 1988, EPA approved the first TMDLs for temperature, bacteria, dissolved oxygen, $\mathrm{pH}$, and phosphorus in the basin (ODEQ 2001). Changes have been made to the TMDLs over the years as needs have arisen, and water quality has improved. However, some rapidly urbanizing areas of the basin still experience water quality problems (Boeder and Chang 2008; Pratt and Chang 2012). CWS is one of the designated management agencies in the basin, and is in charge of monitoring and implementing their TMDL implementation plan. Climate change studies in the region indicate that rising air temperatures will accentuate the seasonal range of stream flows, with flows expected to increase in the winter and decrease in the summer (Hamlet and Lettenmaier 1999; Franczyk and Chang 2009; Chang and Jung 2010; Praskievicz and Chang 2011).

\subsection{Yamhill}

The Yamhill sub-basin lies to the south of the Tualatin, and drains $1,998 \mathrm{~km}^{2}$ (Figure 1). The two main rivers, North and South Yamhill, flow southeast and northeast, respectively, until they converge and flow east before emptying into the Willamette River. Elevation in the basin ranges from 1,084 $\mathrm{m}$ in the Coast Range to $18 \mathrm{~m}$ at the mouth of the Yamhill and has a mean elevation of $217 \mathrm{~m}$. Soils in the basin have similar 
provenance to those in the Tualatin. Annual precipitation ranges from 1,560 to $3,880 \mathrm{~mm}$ in high elevations and 560 to $1,710 \mathrm{~mm}$ in lower elevations. Average daily temperatures at high elevations range from -14 to 12 degrees in the winter and 7 to 27 degrees in the summer. Low elevation daily temperatures range from -10 to 15 degrees in the winter and 10 to 30 degrees in the summer.

The Yamhill River system is much less managed than the Tualatin. There is no major reservoir in the Yamhill to supplement flows or provide flood control; hence, during summer measured flows have dropped to as little as $0.04 \mathrm{cms}$, while winter wet seasons have had flows as large as $1141 \mathrm{cms}$. The runoff ratio is $0.55 .40 \%$ of the basin is forested. One third of the basin consists of cultivated crops. $10 \%$ of the basin consists of shrubland, and only $7 \%$ is developed. 


\section{Data and Methods}

\subsection{Data}

The datasets used for model inputs and calibration can be found in Table 1 .

Select spatial datasets can be visualized in Figure 2. Since sediment and nutrients are not collected continuously at our calibration sites we needed to interpolate loads. Hoyer (2013) use the LOADEST software (Runkel et al. 2004) to estimate a continuous daily time series from a combination of grab samples and continuous monitoring data. The resulting daily time series were then aggregated to monthly loads for model calibration.

Table 1: SWAT model input data and their sources used in the current study

\begin{tabular}{|c|c|c|}
\hline Model Inputs & Description & Source \\
\hline Elevation & $\begin{array}{l}\text { NHDPlus National Elevation Dataset } \\
\text { (NED). }\end{array}$ & NHD Plus (2010) \\
\hline $\begin{array}{l}\text { Historic Land } \\
\text { Cover }\end{array}$ & $\begin{array}{l}\text { National Land Cover Dataset } \\
\text { (NLCD, 2006) }\end{array}$ & USGS (2011) \\
\hline $\begin{array}{l}\text { Urban Growth } \\
\text { Scenarios }\end{array}$ & NLCD based urban growth scenarios & $\begin{array}{l}\text { Hoyer and Chang } \\
\text { (2014) }\end{array}$ \\
\hline $\begin{array}{l}\text { Vectorized } \\
\text { Stream Network }\end{array}$ & $\begin{array}{l}\text { NHDPlus National Hydrography } \\
\text { Dataset }\end{array}$ & NHD Plus (2006) \\
\hline Soils Dataset & $\begin{array}{l}\text { The State Soil Geographic Database } \\
\text { (STATGO) }\end{array}$ & STATSGO (2012) \\
\hline Historic Climate & $\begin{array}{l}\text { Gridded Interpolated } 4 \mathrm{Km} \text { resolution } \\
(1979-2010)\end{array}$ & Abatzoglou (2013) \\
\hline $\begin{array}{l}\text { Future Climate } \\
\text { Scenarios }\end{array}$ & $\begin{array}{l}\text { Three Gridded Interpolated GCM's } \\
(1979-2065)\end{array}$ & Abatzoglou (2012) \\
\hline $\begin{array}{l}\text { Water Quantity } \\
\text { and Quality Data }\end{array}$ & $\begin{array}{l}\text { Stream flow; Sediment, nitrogen and } \\
\text { phosphorus concentrations }\end{array}$ & $\begin{array}{l}\text { ODEQ (2012) \& } \\
\text { USGS (2012) }\end{array}$ \\
\hline $\begin{array}{l}\text { Reservoir and } \\
\text { Point Source } \\
\text { Releases }\end{array}$ & $\begin{array}{l}\text { Daily releases from Hagg Lake, } \\
\text { Barney Reservoir, and WWTPs in } \\
\text { Tualatin and Yamhill }\end{array}$ & $\begin{array}{l}\text { CWS (2011) \& City } \\
\text { of McMinville } \\
(2011)\end{array}$ \\
\hline $\begin{array}{l}\text { Henry Hagg } \\
\text { Lake } \\
\text { Specifications }\end{array}$ & $\begin{array}{l}\text { Henry Hagg Lake physical } \\
\text { characteristics }\end{array}$ & $\begin{array}{l}\text { Ferrari (2001) \& } \\
\text { Sullivan and Rounds } \\
(2005)\end{array}$ \\
\hline
\end{tabular}



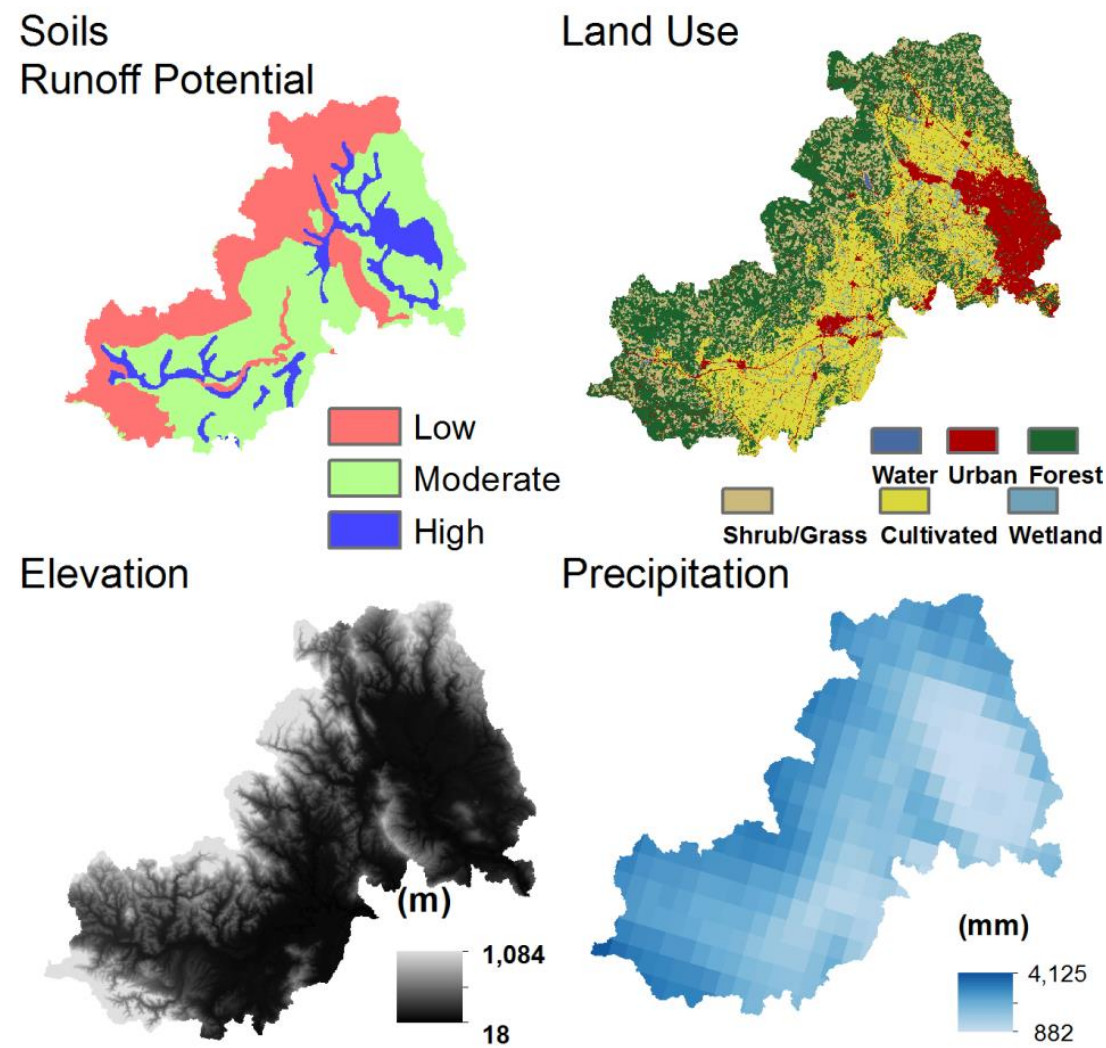

Figure 2: Elevation, soils, land use, and precipitation datasets used in the SWAT model.

\subsection{SWAT Model}

SWAT is a physically based, semi-distributed daily time-step model (SWAT 2012 rev. 613; Arnold et al 1998). It accounts for both terrestrial and in-stream processes. To model flow, SWAT uses the Soil Conservation Service (SCS) curve number approach (SCS 1972). To model sediment transport across the landscape, SWAT uses the Modified Universal Soil Loss Equation (MUSLE, Williams 1975), an event scale variant of the USLE that uses surface runoff instead of precipitation as a measure of erosive 
energy. The nitrogen mass balance is budgeted into five pools and two main categories. Mineral $\mathrm{N}$ consists of the ammonia and nitrate pools, while organic $\mathrm{N}$ consists of the fresh organic $\mathrm{N}$ (biomass) and active and stable organic $\mathrm{N}$ pools. The Phosphorus mass balance is budgeted into six pools split between mineral and organic P. Mineral P consists of the stable, active, and solution pools, while organic $\mathrm{P}$ consists of the stable, active, and fresh (biomass) pools (Neitsch et al. 2011). Channel sediment deposition and re-entrainment are modeled using the Simplified Bangold equation. SWAT models instream nutrient processes with algorithms from the QUAL2E model (Brown and Barnwell 1987).

SWAT models watershed processes at three spatial scales. The first is the watershed. This is essentially the final model output at the mouth of the river. The second meso-scale of analysis is the sub-basin. These are stream reaches and their contributing areas. Users can add additional sub-basins so that a sub-basin's downstream edge corresponds with calibration gages or other important watershed characteristics such as point source inputs. Finally, the most basic unit of analysis in SWAT is the hydrologic response unit (HRU). Each sub-basin has a unique set of HRUs which consist of pixels with similar soil, slope, and land use characteristics. HRUs are aspatial, which means that pixels do not need to be contiguous in order to be grouped together into one HRU. Each HRU can be conceptualized as a field with constant slope, bordering the stream reach. SWAT calculates the flow, sediment and nutrient yields from an HRU, adds it to what was delivered from the upstream reach, and then calculates in-stream processes. Therefore, all yields are assumed to enter the stream at the upper most boundary of its 
sub-basin. This conceptualization enables SWAT to aggregate detailed field level processes and management activities up to the watershed scale (Neitch et al 2011). For example, filter strips and many other best management practices are modeled at the HRU scale. However, the drawback is that the model is not fully distributed and certain spatial processes such as explicit routing of lateral flow between HRUs and unique flow paths to the stream reach are lost.

\subsection{Calibration and Validation}

We chose to perform manual calibration so that interactions between parameters could be captured and multiple calibration objectives could be considered at once. We performed a sensitivity analysis to help inform our parameter selection. We then adjusted the most sensitive parameters to acquire a good fit. We calibrated flow first since it drives sediment and nutrient loads. Since nutrients often travel to the stream bound to sediment we calibrated sediment second and nitrogen and phosphorous last. We used one gage to calibrate the Tualatin, and two additional gages to assess spatial accuracy of Tualatin's calibrated model. We used the USGS Dilley gage (Gage \#1 in Figure 1 and Table 2) for calibration since it is unaffected by the four downstream WWTPs. We used

one gage and one monitoring station to calibrate the Yamhill. We used the USGS gage in McMinville (Gage \# 4 in Figure 1 and Table 2) to calibrate flow, and a DEQ station (Gage \# 5 in Figure 1 and Table 2) to calibrate sediment and nutrients. 
We measured the efficacy of the model with three metrics suggested by Moriasi (2007): Nashe-Sutcliffe Efficiency (NSE), percent bias (PBIAS), and the RMSEobservations standard deviation (RSR).

The NSE is calculated as

$$
N S E=1-\frac{\sum_{i=1}^{n}\left(Y_{i}^{o b s}-Y_{i}^{s i m}\right)^{2}}{\sum_{i=1}^{n}\left(Y_{i}^{\text {obs }}-Y^{m e a n}\right)^{2}}
$$

where $n$ represents the number of observations, $Y_{i}^{\text {obs }}$ is the $i^{\text {th }}$ observed data point, $Y_{i}^{\text {sim }}$ is the $i^{\text {th }}$ simulated data point, and $Y^{\text {mean }}$ is the mean of all the observed data points. If the model perfectly fits the observed data, $N S E=1$. If the model is just as good as taking the mean of the observed data, $N S E=0$. If the mean of the observed data is a better representation than the model, $N S E<0$. We aimed to achieve an NSE score of at least 0.5 (Moriasi 2007).

PBIAS is a measure of the model's tendency to either over or under-predict, and is calculated as

$$
P B I A S=\frac{\sum_{i=1}^{n}\left(Y_{i}^{s i m}-Y_{i}^{o b s}\right) * 100}{\sum_{i=1}^{n}\left(Y_{i}^{o b s}\right)}
$$

If the model on average over predicts, PBIAS is greater than 0 . Under-predictions result in a negative PBIAS. According to Moriasi (2007) PBIAS should be less than $25 \%$ for flow, less than $55 \%$ for sediment, and less than $70 \%$ for nutrients. Using the parameters we chose based off of our sensitivity analysis and the recommended goals outlined by Moriasi (2007), reproducing this calibration should be possible. To acquire exactly the same results it would most likely be better to use a deterministic automatic calibration routine. However, given the computational requirements of automatic calibration, and 
the fact that we did not have a calibration program available to us which could use the three objective functions we chose, we felt the best method to consider all three metrics simultaneously was manual calibration.

The third metric is designed to give a description of the model's absolute error, and is calculated as

$$
R S R=\frac{R M S E}{S T D E V_{o b s}}=\frac{\sqrt{\sum_{i=1}^{n}\left(Y_{i}^{o b s}-Y_{i}^{\text {sim }}\right)^{2}}}{\sqrt{\sum_{i=1}^{n}\left(Y_{i}^{o b s}-Y^{\text {mean }}\right)^{2}}}
$$

Where $R M S E$ is the root mean square error, and $S T D E V_{o b s}$ is the standard deviation of the observed data. Moriasi (2007) recommends that $R S R \leq 0.7$ for all constituents.

Table 2: Gages used for model evaluation. $\mathrm{F}=$ Flow, TSS $=$ Total Suspended Solids, TN $=$ Total Nitrogen, $\mathrm{TP}=$ Total Phosphorus.

\begin{tabular}{lllll}
\hline Gage \# & Name & Organization & ID \# & Constituents \\
\hline 1 & Tualatin River at Dilley & USGS/CWS & 14203500 & F, TSS, TN, TP \\
2 & Fanno Creek at Durham & USGS/CWS & 14206950 & F, TSS, TN, TP \\
3 & $\begin{array}{l}\text { Tualatin River at West } \\
\text { Linn }\end{array}$ & USGS/CWS & 14207500 & F, TSS, TN, TP \\
4 & $\begin{array}{l}\text { South Yamhill River at } \\
\text { McMinnville }\end{array}$ & USGS & 14194150 & F \\
& $\begin{array}{l}\text { Yamhill Water Quality } \\
\text { Station }\end{array}$ & DEQ & 10363 & S, TN, TP \\
\hline
\end{tabular}

\subsection{Scenario Analysis}

\subsubsection{Climate Change}

Three downscaled global climate models with future scenarios for the time period 1981-2065 were selected in order to cover a range of possible realities. The GFDLESM2M (“low”) scenario (MACA 2013) has a $0.08^{\circ} \mathrm{C}$ change in average annual 
temperature, and a $4.47 \%$ increase in average annual precipitation. The MIROC5 (“medium") scenario (MACA 2013) has a $0.87^{\circ} \mathrm{C}$ increase in average annual temperature and a $12.75 \%$ increase in average annual precipitation. The HadGEM2-ES ("high") scenario (MACA 2013) has a $1.38{ }^{\circ} \mathrm{C}$ increase in annual average temperature and a $0.44 \%$ decrease in average annual precipitation. Seasonal changes for the scenarios can be seen in Figure 3. The low scenario sees precipitation increase in both winter and summer seasons. Precipitation increases during the winter and decreases substantially during the summer in the medium scenario. Finally, precipitation remains roughly the same during the winter, but decreases substantially during the summer in the high scenario.

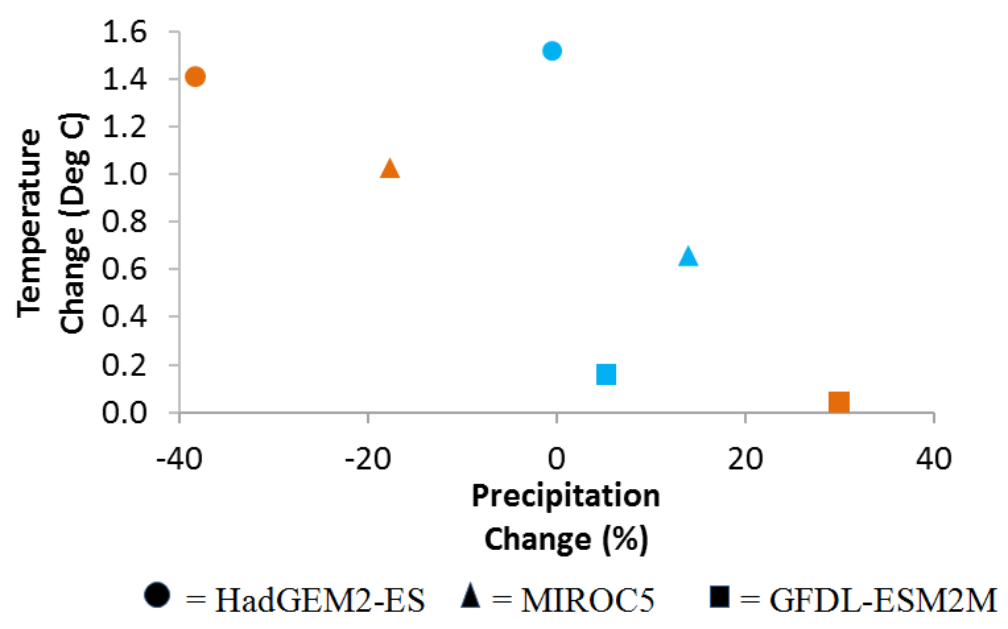

Figure 3: Area weighted changes in precipitation and temperature for each of the three climate scenarios split by season (Winter=DJF, Summer=JJA).

\subsubsection{Urban Growth}


Hoyer and Chang (2014), with relevant stakeholder consultation, developed land cover change scenarios reflecting possible expansion of urban areas centered on the year 2050. The relative growth of urban areas was based on historical growth rates and projected increases in annual population in the study area. The low scenario assumes an annual growth rate of $0.6 \%$ and the high scenario assumes a $2.0 \%$ annual growth rate. Land conversion is based on a graded weight matrix comprised of six factors: urban growth boundary (UGB), distance from the UGB, zoning, groundwater restriction zones, high value farm soils, and measure 49 claims which provide exemptions to landowners who purchased land inside the urban growth boundary (UGB) before the UGB regulations were instituted. A spatial mask was used to exclude urban growth from protected lands.

\subsubsection{Management}

We apply the Vegetative Filter Strip model in SWAT for two representative years in the study period (WY 1994 and 1995). The model was developed from the Vegetative Filter Strip MODel (VFSMOD, Munoz-Capena, 1999), and designed to apply to HRUs in SWAT. The algorithm permits a percentage of overland flow to be filtered before it leaves an HRU and enters the stream reach. When overland flow encounters vegetation it slows and its sediment carrying capacity becomes reduced. It also provides extra time for runoff to infiltrate the soil and deposit sediment along with it. 
For the sake of simplicity, the VFS model in SWAT assumes that the amount of TN and TP filtered out of overland flow is related to sediment reduction. This is assumption is backed up by studies demonstrating that the bulk of nitrogen and phosphorus travel in particulate form off of agricultural fields (White and Arnold 2009).

We apply the VFS model to 5 sub-basins that exhibit the top 5\% sediment and nutrient loads based on a weighted index over the 30 year historic period. The weighted index is comprised of sediment, TN, and TP yields using the following formula:

$$
I=0.5 S+0.25 N+0.25 P
$$

$I$ is the index value, $\mathrm{S}$ is the sediment yield (tons/ha), $N$ is the TN yield (kg/ha), and $P$ is the TP yield (kg/ha). We gave sediment the highest weight since in high concentrations it is considered a pollutant and it transports both nitrogen and phosphorus, two nutrients commonly found to exceed natural concentrations as a result of agricultural activities and urban development (ODEQ 2001). 


\section{Results}

\subsection{Model Calibration}

Table 3 reports a summary of the twelve fitted parameter values. Due to a lack of empirical data on channel erodibility, and sediment sources and sinks, we calibrated sediment using MUSLE parameters only. Uncertainties in measured data, LOADEST estimates, and temporal non-stationarity in flow, sediment and nutrient loadings, mean that these values represent estimates of true parameter values only. Metrics were all in acceptable ranges according to Moriasi et al. (2007) during calibration. RSR values for TN and TP at the DEQ station were slightly higher than the recommended value of 0.7 during validation, but all other metrics had acceptable values. Table 4 shows a summary of monthly model fit metrics.

Table 3: List of final calibrated parameters for Tualatin and Yamhill sub-basins.

\begin{tabular}{|c|c|c|c|c|c|}
\hline Description & Parameter & Min & $\operatorname{Max}$ & $\begin{array}{c}\text { Tualatin } \\
\text { Value }\end{array}$ & $\begin{array}{c}\text { Yamhill } \\
\text { Value }\end{array}$ \\
\hline \multicolumn{6}{|c|}{ Flow } \\
\hline $\begin{array}{l}\text { Baseflow alpha factor } \\
\text { (days) }\end{array}$ & v_ALPHA_BF.gw* & 0 & 1 & 1 & 1 \\
\hline $\begin{array}{l}\text { Soil evaporation } \\
\text { compensation factor }\end{array}$ & v_ESCO.bsn & 0.01 & 1 & 1 & 0 \\
\hline $\begin{array}{l}\text { Plant uptake compensation } \\
\text { factor }\end{array}$ & v_EPCO.bsn & 0 & 1 & 0.01 & 1 \\
\hline $\begin{array}{l}\text { Available water capacity of } \\
\text { the soil layer }\end{array}$ & r_SOL_AWC().sol & -0.2 & 0.2 & -0.2 & -0.2 \\
\hline $\begin{array}{l}\text { Threshold depth of water in } \\
\text { the shallow aquifer required } \\
\text { for return flow to occur } \\
(\mathrm{mm})\end{array}$ & v_GWQMN.gw & 0 & 5000 & 0.1 & 0.1 \\
\hline \multicolumn{6}{|c|}{ Sediment } \\
\hline Average slope length & $\begin{array}{c}\text { r__SLSUBBSN.hru } \\
16\end{array}$ & 10 & 150 & -0.7 & -0.4 \\
\hline
\end{tabular}


Min value of USLE C

$\begin{array}{llllll}\text { factor applicable to the land } \quad \text { r_USLE_C.crop.dat } & 0.001 & 0.5 & 0.01 & 0.01\end{array}$ cover/plant (Forest)

USLE equation soil erodibility $(\mathrm{K})$ factor r_USLE_K().sol $\quad 0 \quad 0.65 \quad-0.7 \quad-0.3$

Average Slope Steepness r_HRU_SLP.hru

\begin{tabular}{llll}
0 & 1 & -0.6 & -0.2 \\
\hline
\end{tabular}

Nitrogen

Nitrogen percolation coefficient v__NPERCO.bsn

$\begin{array}{lll}0.1 & 1 & 0.01\end{array}$

0.1

Denitrification exponential rate coefficient v_CDN.bsn

$0.1 \quad 3$

0.1

0.1

Denitrification threshold water content

v__SDNCO.bsn

$0.1 \quad 1$

$*_{\mathrm{v}}$ : Parameter is assigned this value. $\mathrm{r}$ : Parameter is multiplied by $1+$ this value.

Table 4: Monthly calibration and validation results.

\begin{tabular}{lcccccc}
\hline & \multicolumn{3}{c}{ Calibration } & \multicolumn{3}{c}{ Validation } \\
\hline & NSE & PBIAS & RSR & NSE & PBIAS & RSR \\
\hline \multicolumn{6}{c}{ Dilley* } \\
\hline Flow & 0.93 & -0.7 & 0.27 & 0.92 & -7.8 & 0.28 \\
Sediment & 0.67 & 53 & 0.57 & 0.66 & 45.7 & 0.58 \\
TN & 0.56 & -6.3 & 0.66 & 0.76 & 32.6 & 0.49 \\
TP & 0.65 & -26.6 & 0.59 & 0.76 & -1.1 & 0.49 \\
\hline \multicolumn{6}{c}{ Yamhill* } \\
\hline Flow & 0.92 & -16.4 & 0.28 & 0.91 & -16.6 & 0.3 \\
Sediment & 0.69 & -9.4 & 0.55 & 0.82 & 11.8 & 0.42 \\
TN & 0.51 & 24.4 & 0.7 & 0.57 & 20.7 & 0.73 \\
TP & 0.54 & 1.2 & 0.68 & 0.72 & 25.8 & 0.72 \\
\hline \multicolumn{7}{c}{ Fanno } \\
\hline Flow & 0.92 & 0.9 & 0.28 & 0.9 & 1.7 & 0.31 \\
Sediment & 0.17 & -57.4 & 0.91 & 0.08 & -61.6 & 0.96 \\
TN & 0.24 & -34 & 0.87 & 0.14 & -30.9 & 0.93 \\
TP & 0.32 & -55 & 0.82 & 0.32 & -53.7 & 0.82 \\
\hline \multicolumn{6}{c}{ West Linn } \\
\hline Flow & 0.93 & 11 & 0.27 & 0.94 & 9.5 & 0.25 \\
Sediment & 0.63 & 52.2 & 0.61 & 0.29 & 118.6 & 0.84 \\
TN & 0.6 & -33 & 0.63 & 0.67 & 3.6 & 0.57 \\
TP & 0.28 & -57.5 & 0.85 & 0.57 & -40.4 & 0.66 \\
\hline *Gages used for calibration and validation
\end{tabular}




\subsection{Future Changes Under Climate and Land Cover Change Scenarios}

\subsubsection{Flow}

Average annual basin-wide flows increase in all scenarios due to the combination of urbanization and increased precipitation. While there is a slight decrease in annual precipitation in the high climate scenario, impervious surfaces decrease infiltration and contribute to a slight increase in annual water yield (Table 5).

Changes in wintertime flows follow the same pattern as annual flows since a significant portion of precipitation falls during winter months. In all scenarios wintertime flow increases by a greater percentage than precipitation due to increased impervious surfaces. Fall is the only season where precipitation increases in the high climate scenario (Figure 4). The slight lag between precipitation and runoff means that flows still increase during the winter despite a slight decrease in rain in winter. The lag between runoff and precipitation can be seen clearly in all scenarios. Peak flows typically occur a month or two after precipitation (Figure 4).

Summertime flows have a mixed response. In the low climate scenario flows increase by a smaller percentage than precipitation due to increased evapotransporation. In the medium climate scenario, summer-time flows contain a large baseflow component due to large winter and spring rains (Figure 4). These groundwater inputs enable summer-time flows to increase despite a decrease in summer precipitation greater than 
$15 \%$. Under the high scenario, summer-time flow decreases by a smaller percentage than precipitation due to more evapotranspiration. 
(a)

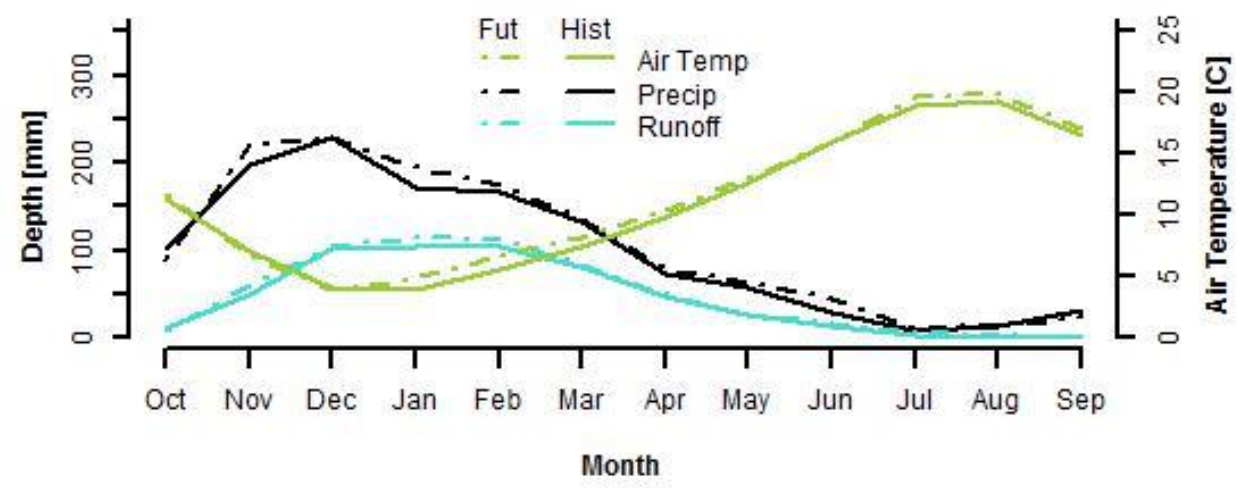

(b)

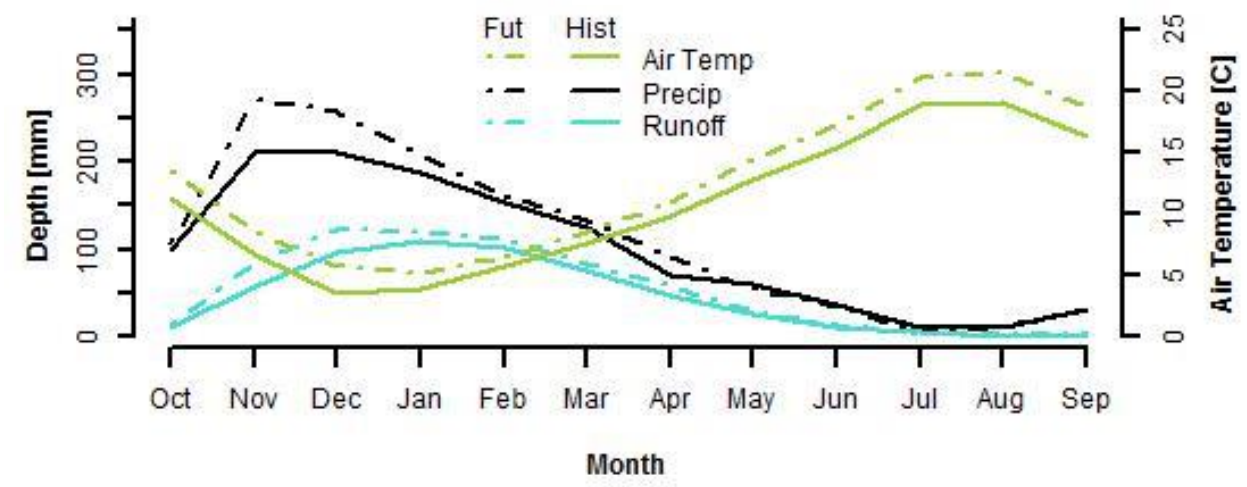

(c)

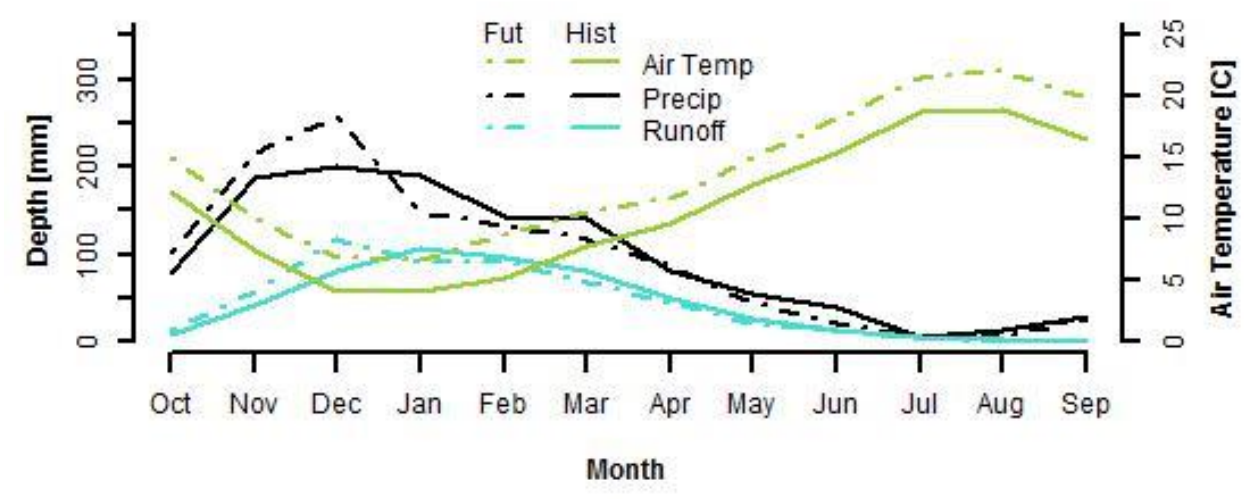


(d)

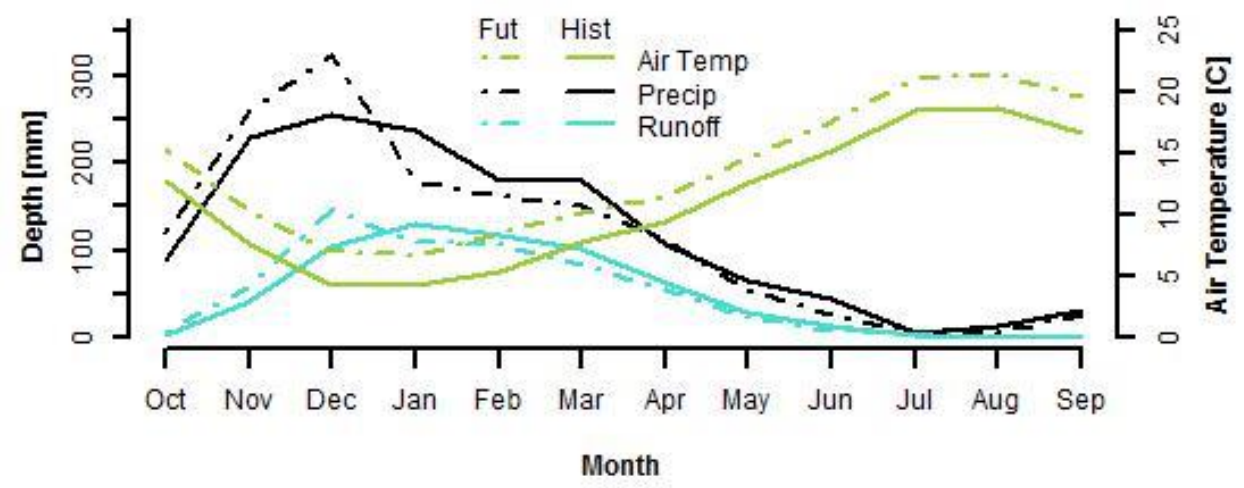

(e)

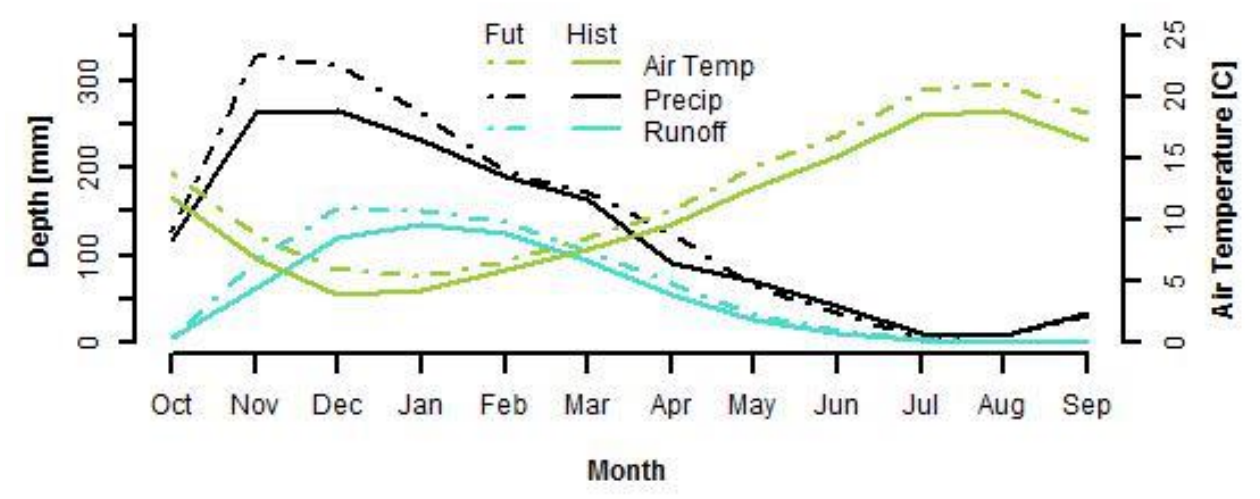

(f)

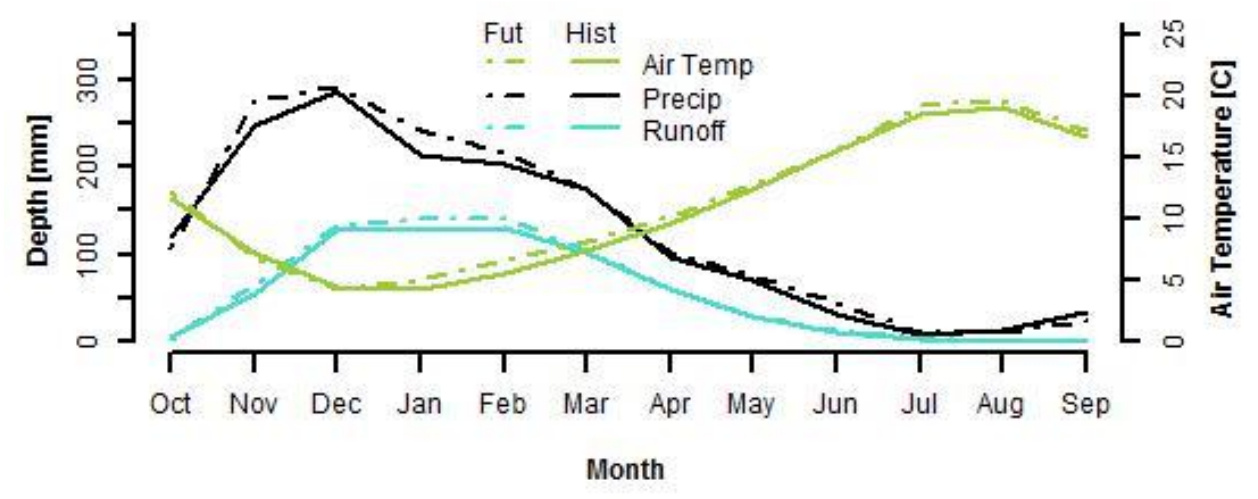

Figure 4: Changes in precipitation, air temperature, and flow for the high urban scenario for Tualatin: low (a), medium (b), and high (a) climate scenarios. Yamhill: low (d), medium (e), high (f) climate scenarios. 
At the annual scale the spatial patterns of changes to water yield are fairly uniform and reflect changes in precipitation (Figure 5). A few sub-basins that are located near urban areas see significant decreases in percolation due to urbanization and therefore have increases in annual water yield as high as $31 \%$. These patterns are the same throughout the winter months. During the summer months (Figure 6), urbanized areas have less groundwater to supplement flows. As a result, these sub-basins see decreases in the medium and high scenario, both of which have decreased summer precipitation. The low scenario has more summer precipitation, so the urban areas see summer water yield increase.

Table 5: Percent change in annual and seasonal precipitation and flow for Tualatin and Yamhill under climate change and urban growth scenarios.

\begin{tabular}{|c|c|c|c|c|c|c|}
\hline & \multicolumn{3}{|c|}{ Tualatin } & \multicolumn{3}{|c|}{ Yamhill } \\
\hline & $\begin{array}{c}\text { Precipitation } \\
(\%)\end{array}$ & \multicolumn{2}{|c|}{$\begin{array}{c}\text { Flow } \\
(\%)\end{array}$} & $\begin{array}{c}\text { Precipitation } \\
(\%)\end{array}$ & \multicolumn{2}{|c|}{$\begin{array}{c}\text { Flow } \\
(\%)\end{array}$} \\
\hline \multirow[t]{3}{*}{ Climate } & & \multicolumn{2}{|c|}{ Land Use } & & \multicolumn{2}{|c|}{ Land Use } \\
\hline & & Low & High & & Low & High \\
\hline & \multicolumn{6}{|c|}{ Annual } \\
\hline Low & 5.17 & 6.1 & 6.14 & 4.15 & 6.2 & 6.29 \\
\hline Medium & 12.72 & 18.8 & 19.13 & 13.13 & 24.61 & 19.47 \\
\hline \multirow[t]{2}{*}{ High } & -0.12 & 0.86 & 1.12 & -0.25 & 0.69 & 0.04 \\
\hline & \multicolumn{6}{|c|}{ Winter } \\
\hline Low & 6.3 & 6.07 & 6.07 & 4.3 & 7.33 & 7.34 \\
\hline Medium & 13.36 & 16.23 & 16.22 & 14.04 & 16.81 & 16.79 \\
\hline \multirow[t]{2}{*}{ High } & -0.35 & 6.41 & 6.4 & -0.14 & 4.86 & 4.87 \\
\hline & \multicolumn{6}{|c|}{ Summer } \\
\hline Low & 31.85 & 25.16 & 25.16 & 30.05 & 18.97 & 19 \\
\hline Medium & -16.49 & 5.67 & 5.32 & -19.14 & 8.08 & 8.03 \\
\hline High & -40.24 & -30.16 & -30.9 & -36.56 & -28.11 & -28.14 \\
\hline
\end{tabular}




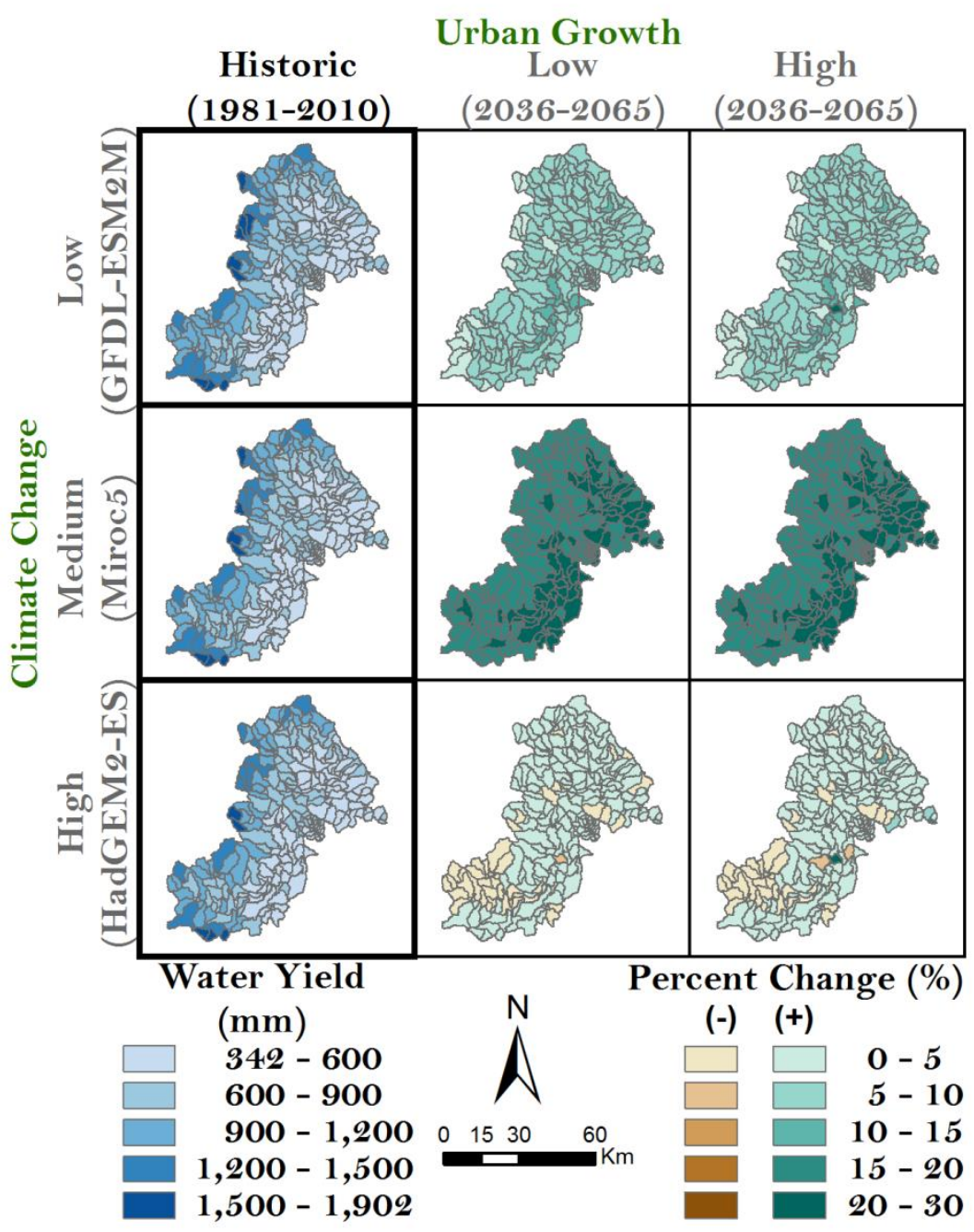

Figure 5: Percent change in average annual water yield by sub-basin. 


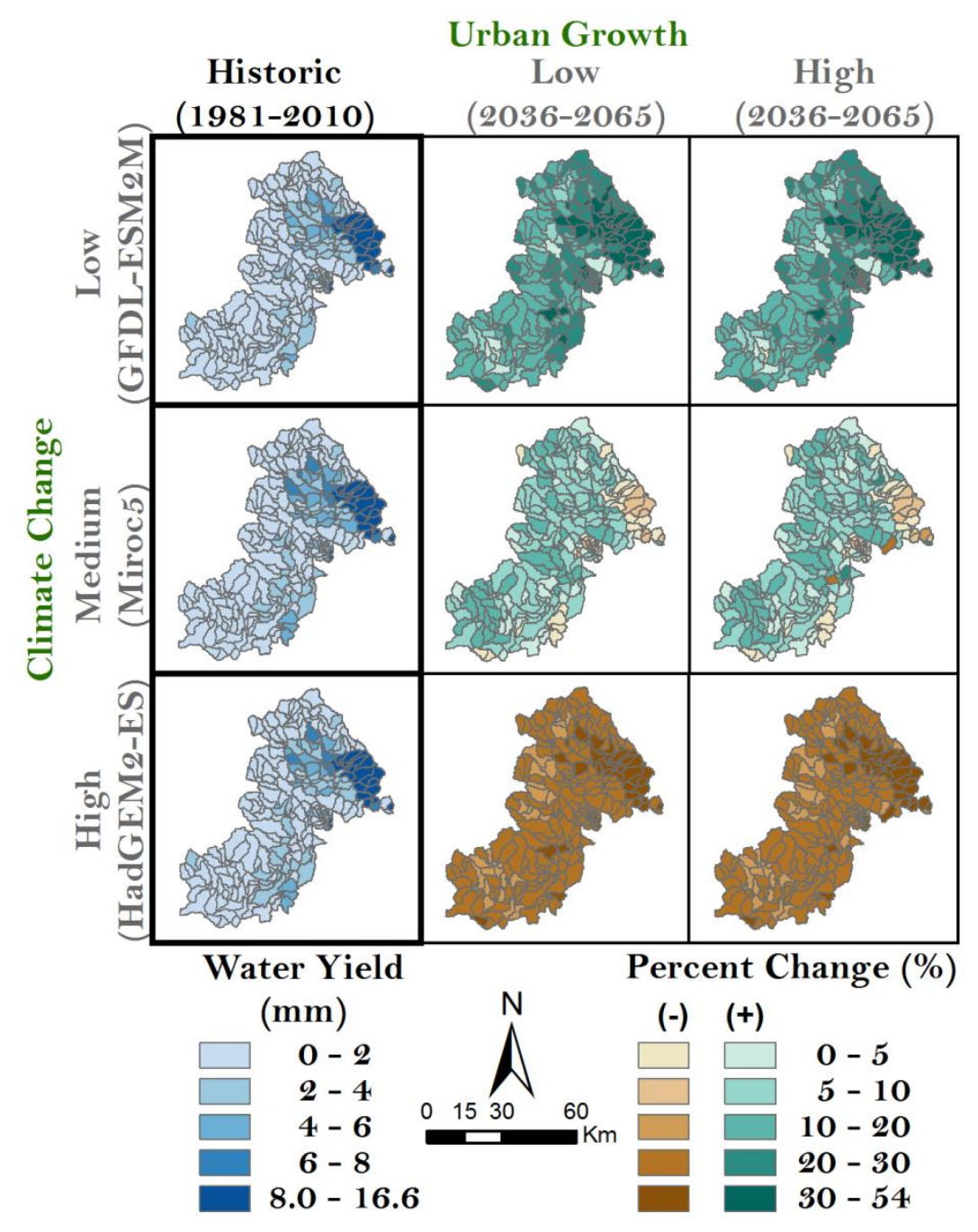

Figure 6: Percent change in average summer water yield.

\subsubsection{Sediment}

There are basin-wide decreases in sediment in Tualatin under the low climate scenario annually and during the winter despite increases in impervious surfaces (Table 6). Erosion increases during the summer due to a $31.8 \%$ increase in precipitation. Yamhill sees uniform increases in sediment under the low climate scenario due to less 
urban growth which permits moderate increases in precipitation to increase erosion. Both basins see increases in sediment during the medium scenario, reflecting the universal increase in precipitation and flows for the basin. While Tualatin sees sediment increase under the high climate scenario both annually and during the winter, Yamhill has a decrease annually and a slight increase during the winter. Some of the shifts in sediment seem counter intuitive when compared to the precipitation changes.

Table 6: Percent change in annual and seasonal sediment loadings

\begin{tabular}{lll|lr}
\hline & \multicolumn{2}{c|}{ Tualatin } & \multicolumn{2}{c}{ Yamhill } \\
\hline \multicolumn{4}{c}{ Climate } & \multicolumn{4}{c}{ Land Use } \\
\hline & Low & High & \multicolumn{1}{c}{ Low } & High \\
\hline \multicolumn{5}{c}{ Annual } \\
\hline Low & -7.6 & -7.64 & 6.5 & 6.77 \\
Medium & 38.5 & 48.17 & 29.6 & 22.19 \\
High & 17.58 & 27.69 & -2.84 & -2.63 \\
\hline \multicolumn{5}{c}{ Winter } \\
\hline Low & -11.95 & -11.95 & 6.88 \\
Medium & 33.85 & 42.29 & 16.22 & 7.26 \\
High & 24.27 & 33.9 & 1.75 \\
\hline \multicolumn{5}{c}{ Summer } \\
\hline Low & 81.96 & 82 & 73.06 \\
Medium & 6.82 & 13.38 & 5.62 & 73.04 \\
High & -44.37 & -42.45 & -38.91 \\
\hline
\end{tabular}

The spatial patterns of sediment yields suggest areas of high slope exhibit the highest sediment yields (near the basin boundaries), reflecting the important role slope plays in erosional processes (Figure 7). Cultivated agricultural lands are located on fairly flat terrain, and therefore do not exhibit erosion rates as high as those for hay and rangeland which are located on a mix of flat and high sloping areas. Changes in erosion resulting from climate change respond in unpredictable ways. Forest, hay and range lands 
may see increases in erosion under one climate scenario, but see a decrease in another.

Neither land cover, nor slope appears to dictate this pattern. While the low scenario has a greater increase in precipitation than the high scenario, the high scenario has a greater increase in erosion. Urban areas see a consistent increase in erosion rates.

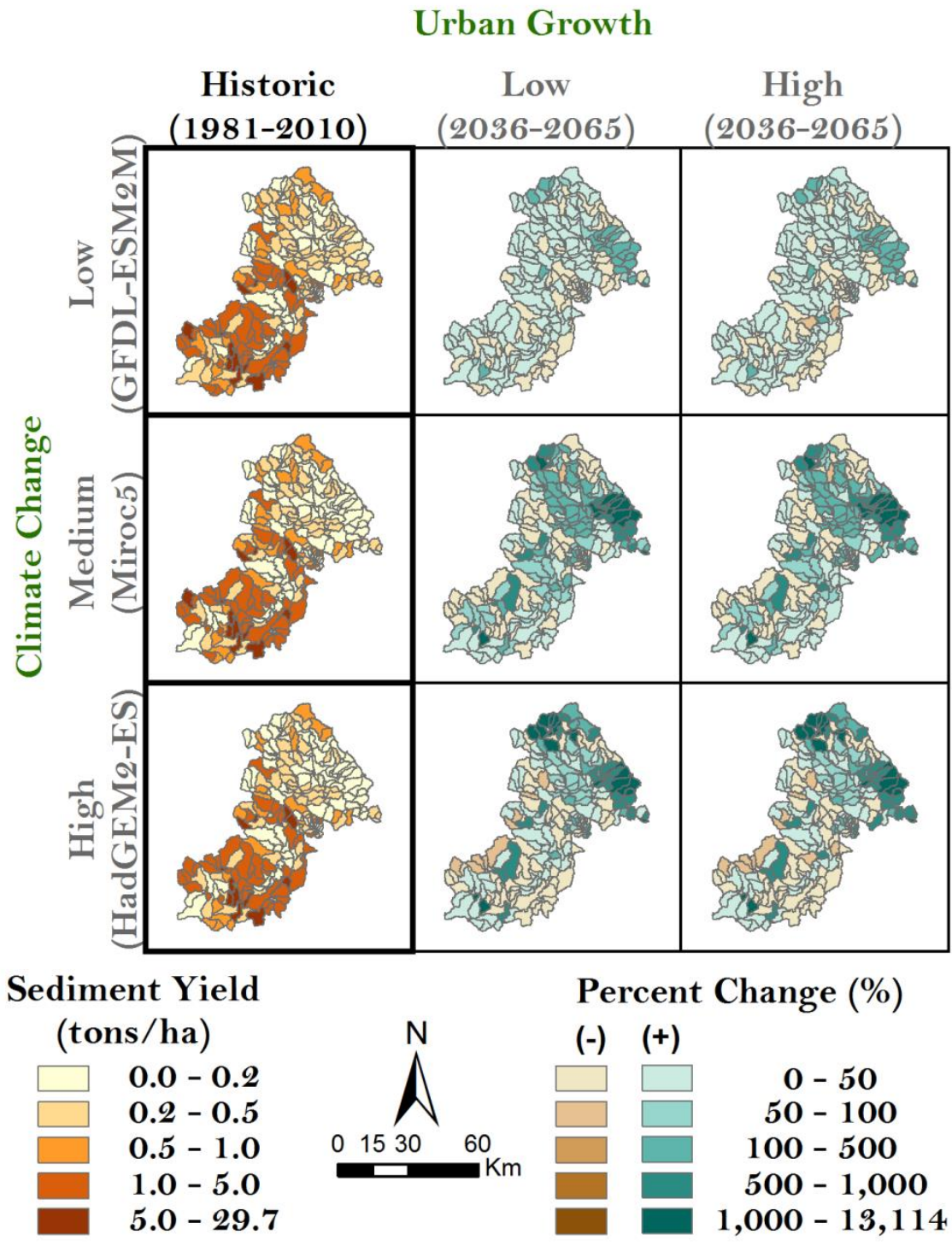

Figure 7: Percent change in annual average sediment yields.

\subsubsection{Total Nitrogen}


Total nitrogen travels to the stream through lateral flow, overland flow, and transport with sediment. TN increases annually and during the winter for all climate scenarios reflecting increased transport from higher flows (Table 7). The only decreases are seen under the medium and high climate scenarios where there are decreases in precipitation. Yamhill sees either smaller increases, or larger decreases under the high urbanization scenarios due to conversion of high nutrient yielding lands to lower yielding urban lands. Tualatin sees this same pattern for the medium climate scenario, but more mixed results for the low and high scenarios.

Table 7: Percent change in annual and seasonal TN loadings.

\begin{tabular}{|c|c|c|c|c|}
\hline \multirow{3}{*}{ Climate } & \multicolumn{2}{|c|}{ Tualatin } & \multicolumn{2}{|c|}{ Yamhill } \\
\hline & \multicolumn{4}{|c|}{ Land Use } \\
\hline & Low & High & Low & High \\
\hline \multicolumn{5}{|c|}{ Annual } \\
\hline Low & 13.9 & 13.93 & 4.6 & 4.07 \\
\hline Medium & 48.7 & 48.27 & 21.67 & 21.01 \\
\hline High & 28.15 & 28.26 & 2.78 & 2.20 \\
\hline \multicolumn{5}{|c|}{ Winter } \\
\hline Low & 17.75 & 17.75 & 6.25 & 5.52 \\
\hline Medium & 59.38 & 59.07 & 20.49 & 19.62 \\
\hline High & 56.83 & 57.14 & 12.65 & 11.78 \\
\hline \multicolumn{5}{|c|}{ Summer } \\
\hline Low & 78.6 & 78.61 & 64.6 & 63.88 \\
\hline Medium & 0.002 & -1.58 & -31.97 & -32 \\
\hline High & -64.04 & -64.24 & -70.55 & -70.83 \\
\hline
\end{tabular}

Spatial patterns of TN yield show the importance of slope (Figure 8). Range lands and lands under hay production with higher slopes produce the highest yields. Cultivated agricultural lands lie on more gently sloping valley lands and do not 
demonstrate as heavy an impact in the model. Urbanizing sub-basins show large

increases in nutrients. Areas which have historically low nutrient yields also see greater proportionate increases in yields. These patterns closely follow those of sediment.

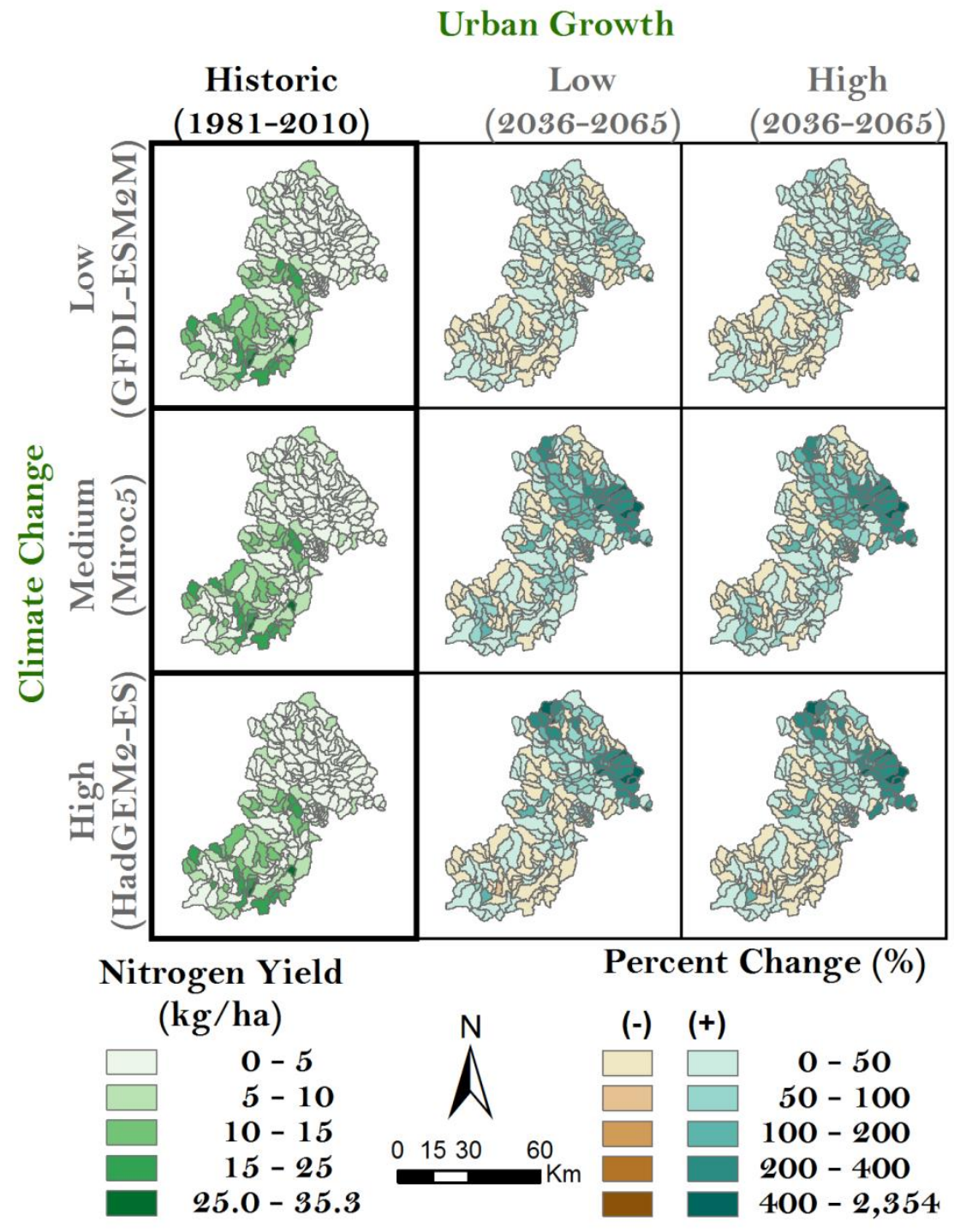

Figure 8: Percent change in annual average TN yield.

\subsubsection{Total Phosphorus}


Total phosphorus travels to the stream attached to sediment, in solution with overland flow, in mineral form, and with groundwater. The Tualatin sees annual increases in TP throughout all climate scenarios, while Yamhill sees an increase only in the medium scenario (Table 8). In Yamhill, the high urban growth scenarios show slightly larger decreases in annual and winter TP loads than the low urban growth scenario. In the summer Yamhill has slightly larger increases or slightly smaller decreases in the high urban growth scenario. The largest increases in TP occur during the summer in the low climate scenario due to a $30 \%$ increase in precipitation.

Spatial patterns of TP follow those of sediment. There are large increases in the Portland metro area as well as in the higher elevations of the coast range in the Tualatin (Figure 9) as a result of high sloping urban lands and areas harvested for timber.

Table 8: Percent change in annual and seasonal TP loadings.

\begin{tabular}{|c|c|c|c|c|}
\hline \multirow{3}{*}{ Climate } & \multicolumn{2}{|l|}{ Tualatin } & \multicolumn{2}{|c|}{ Yamhill } \\
\hline & \multicolumn{4}{|c|}{ Land Use } \\
\hline & Low & High & Low & High \\
\hline & \multicolumn{4}{|c|}{ Annual } \\
\hline Low & 4.7 & 4.67 & -15.7 & -15.83 \\
\hline Medium & 68.8 & 73.94 & 1.55 & 1.47 \\
\hline \multirow[t]{2}{*}{ High } & 58.75 & 64.93 & -17.85 & -17.89 \\
\hline & \multicolumn{4}{|c|}{ Winter } \\
\hline Low & 1.12 & 1.12 & -18.32 & -18.51 \\
\hline Medium & 57.11 & 60.9 & -11.51 & -11.66 \\
\hline \multirow[t]{2}{*}{ High } & 78.77 & 85.13 & -17.82 & -17.87 \\
\hline & \multicolumn{4}{|c|}{ Summer } \\
\hline Low & 359 & 359 & 596.21 & 598.38 \\
\hline Medium & -57.24 & -52.4 & -76.97 & -76.08 \\
\hline High & -77.69 & -75.74 & -70.8 & -70.37 \\
\hline
\end{tabular}




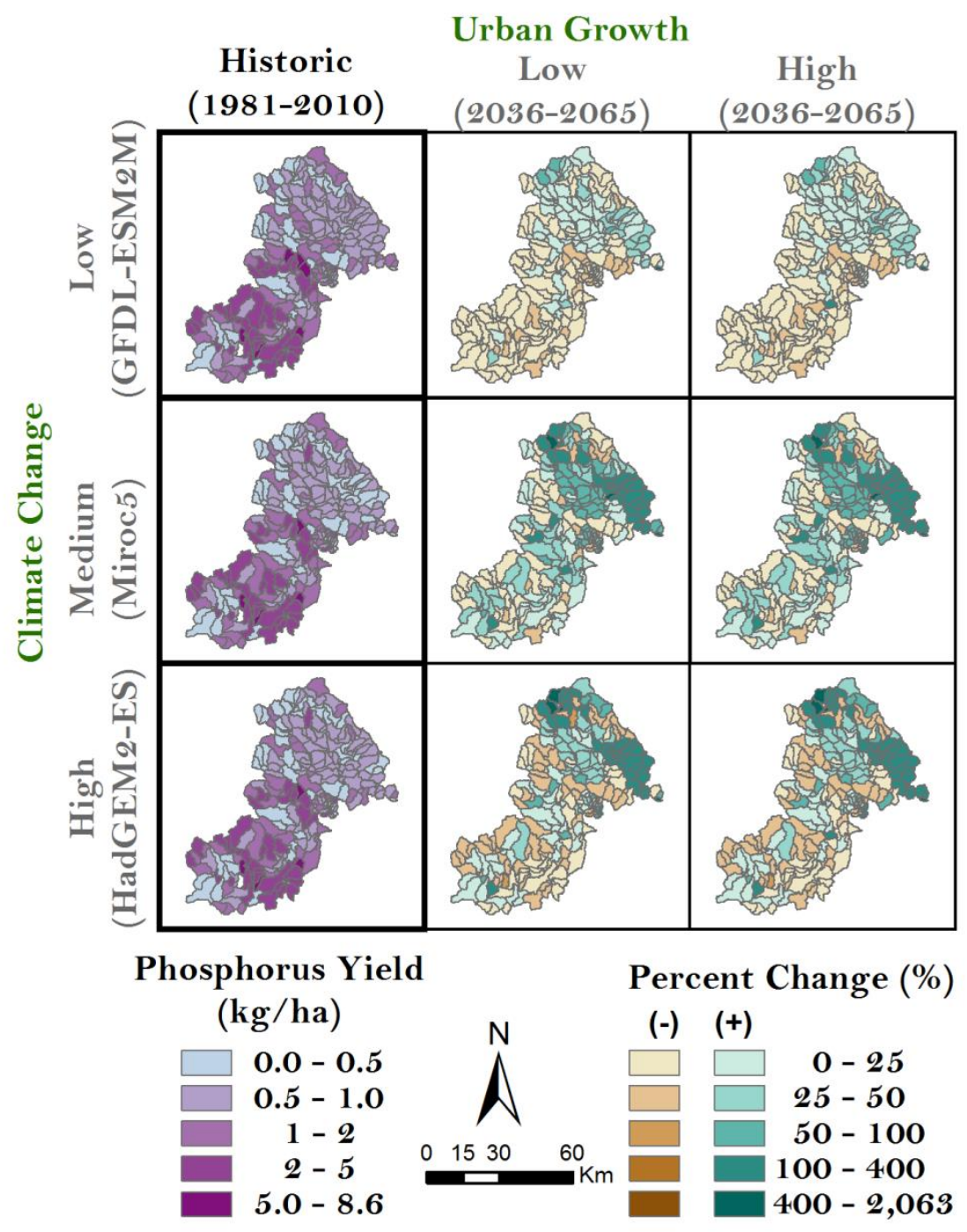

Figure 9: Percent change in annual average TP yields.

4.3 Location of CSAs 
The top $1 \%$ of sub-basins have an average index of 19.4 . The bottom $1 \%$ have an average index of 0.05 . Out of the sub-basins in the study site, the top $12 \%$ are in the Yamhill basin, signifying the proportionately high sediment exports predicted by the model. The top 5\% index values for each basin can be visualized in Figure 9. Many CSA's remain the same while some hotspots shift according to the spatial patterns created by climate change and urbanization discussed previously. The high climate scenario sees 6 CSAs shift. The medium scenario sees 5 shift, and the low scenario sees only 3 CSAs shift.

At the HRU level, relationships between land cover and topography can be seen more directly than at the sub-basin scale due to averaging. Hotspots at the HRU scale consist of high sloping hay and range land. The average basin-wide slope in Tualatin is $14.7 \%$, while the area weighted average slope for HRU CSAs is $30.5 \%$. In Yamhill, the basin-wide slope is $17.3 \%$, while the average slope for HRU CSAs is $23.7 \%$. The dominant land use in HRU CSAs for Tualatin is rangeland (88\%) and hay (12\%). The dominant land use in HRU CSAs for Yamhill is Hay (54\%) and rangeland (46\%). 


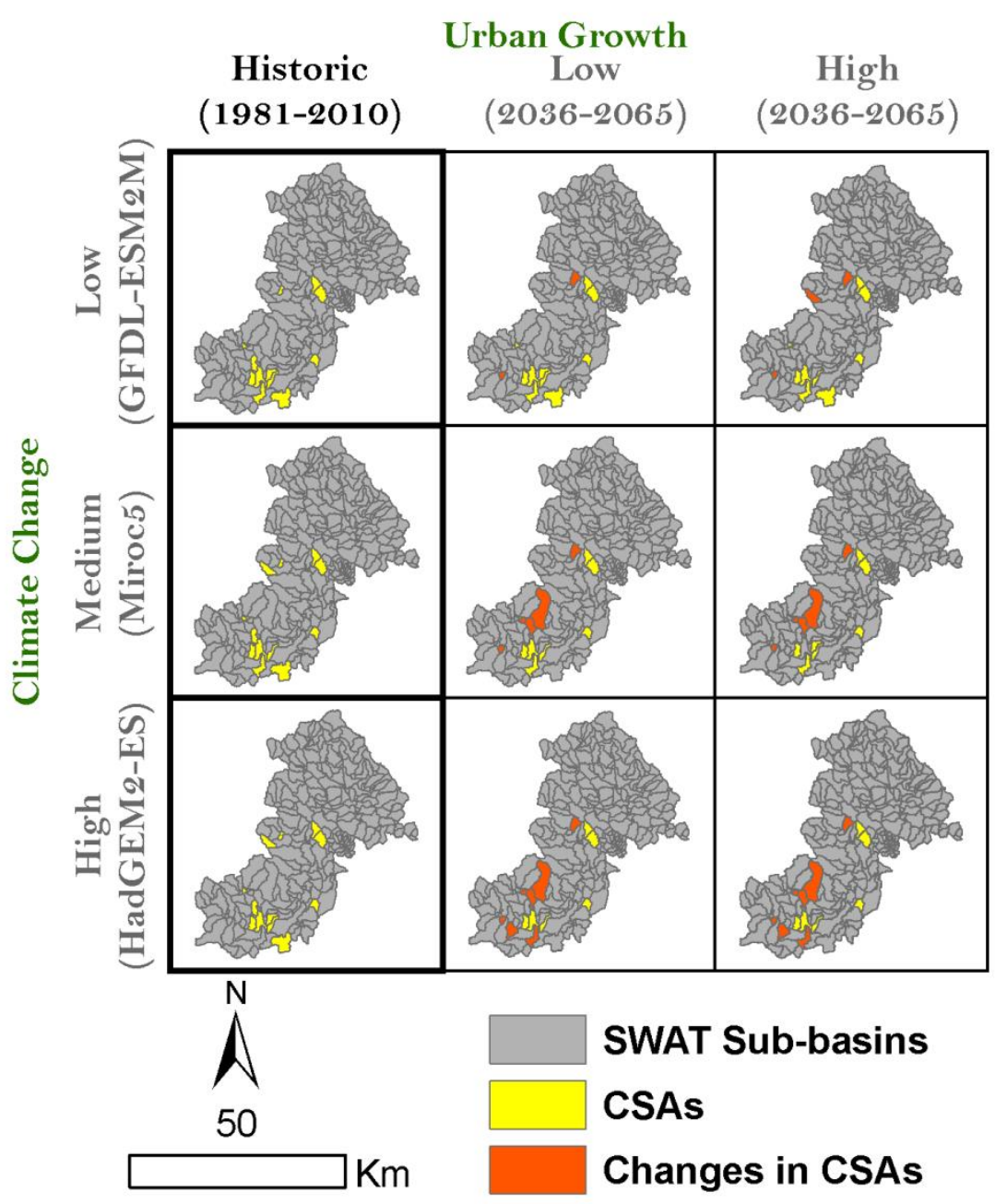

Figure 10: Shifts in hotspots due to climate change and urbanization.

\subsection{Management}

Application of vegetative filter strips has an average rate of reduction of $61.4 \%$ for erosion, $49.2 \%$ for $\mathrm{TN}$, and $62.9 \%$ for $\mathrm{TP}$. The low flow year had a larger reduction in sediment and nutrients (S: 65.7, TN: 51.2, TP: 65.5\%) than the high flow year (S: 
57.7, TN: 47.3, TP: $60.3 \%$ ). Index values dropped on average $54.5 \%$, bringing all but the most extreme sub-basins out of the top 5\% (Table 9).

Table 9: Comparison of top 5\% sub-basins before and after VFS applied

\begin{tabular}{ccc|cc}
\hline \multicolumn{3}{c}{$\begin{array}{c}\text { No } \\
\text { management }\end{array}$} & \multicolumn{2}{c}{ VFS } \\
\hline $\begin{array}{c}\text { Sub- } \\
\text { basin }\end{array}$ & Index & Rank & Index & Rank \\
\hline 82 & 31.07 & 1 & 15.66 & 1 \\
89 & 16.55 & 2 & 7.50 & 16 \\
90 & 16.51 & 3 & 7.13 & 19 \\
12 & 13.79 & 4 & 6.54 & 25 \\
16 & 12.81 & 6 & 5.24 & 33 \\
\hline
\end{tabular}




\section{Discussion}

\subsection{Model Calibration}

Results of model calibrations were mixed (Table 4). Flow simulations track well with observed data in both basins, and the spatial patterns of water yield make sense given the known orographic effects of the coast range (Figure 10).

Sediment calibration in the Yamhill was acceptable. Model assessment at other parts of the Yamhill was not possible due to lack of data, but the homogenous land cover characteristics throughout the basin may make it safe to assume the model performs well throughout. Sediment calibrations in the Tualatin were acceptable at the Dilley and West Linn gage. However, the Fanno gage needs improvement. The poor performance is likely due to SWAT's inability to effectively capture physical processes unique to urban areas. SWAT assumes urban areas consist of impervious surfaces and Bermuda grass. This assumption is likely too simplistic. For example, we'd expect SWAT to under predict sediment loads in urban areas which have yards with more exposed soils. This may be one explanation for the negative bias in sediment results. However, this alone cannot account for SWAT's deficiencies in Fanno Creek since the NSE and RSR are also poor, meaning the model is not simply under predicting, but differs erratically from the observed data. One possible explanation is that SWAT cannot capture in-stream processes unique to small urban watersheds. Urban streams are known to function differently than undisturbed streams. In particular, a larger percentage of sediment 
originates from channel erosion rather than hill slope processes (Paul and Meyer 2001). This channel erosion can happen in response to storm events, or as a result of construction near the stream. These types of discontinuous processes would cause sediment loads to vary sporadically over both short and long time periods, and may explain SWAT's poor performance. Spatial patterns of sediment yield are sensible, but due to the poor calibration results for Fanno Creek, the results in this part of the basin have less certainty. As a result, our confidence in the precise changes that may take place is smaller in Fanno Creek than in other portions of the basin.

Nutrient calibrations are acceptable for the Dilley and Yamhill DEQ calibration points, but were unsatisfactory for the West Linn and Fanno gages. This makes sense since there are two waste water treatment plants above the West Linn gage which release water with varying concentrations of nutrients throughout the year. While flow from these plants were included in the model, estimates of nutrient concentrations were difficult to derive. As a result these sources of nutrients were excluded from the model. This would explain the under prediction of both TN and TP at the West Linn gage. As for Fanno Creek, since nutrients tend to travel with sediment, the poor sediment results may also explain the poor nutrient results. Spatial patterns of nutrient yield appear sensible in the Tualatin where yields roughly track sediment yields.

\subsection{Spatial Patterns of Flow, Sediment, and Nutrients}


The spatial patterns of SWAT output can be seen in Figure 10. These patterns constitute a mix of natural processes, model structure, and underlying model assumptions. Orographic effects from the Coast Range create a clear east-west gradient in water yield with higher yields in the higher elevations to the west, and lower yields in the valleys of the two basins. Summer water yield is larger in urban areas (Figure 6) than the rest of the basin. One would expect baseflow in the higher elevations to sustain water yield throughout the basin at higher levels than the urban areas. A more complete analysis of sub-surface flows in the model could explain why this pattern is taking place. One explanation is that baseflows during the summer are not enough to overtake the immediate runoff that will take place in urban areas.

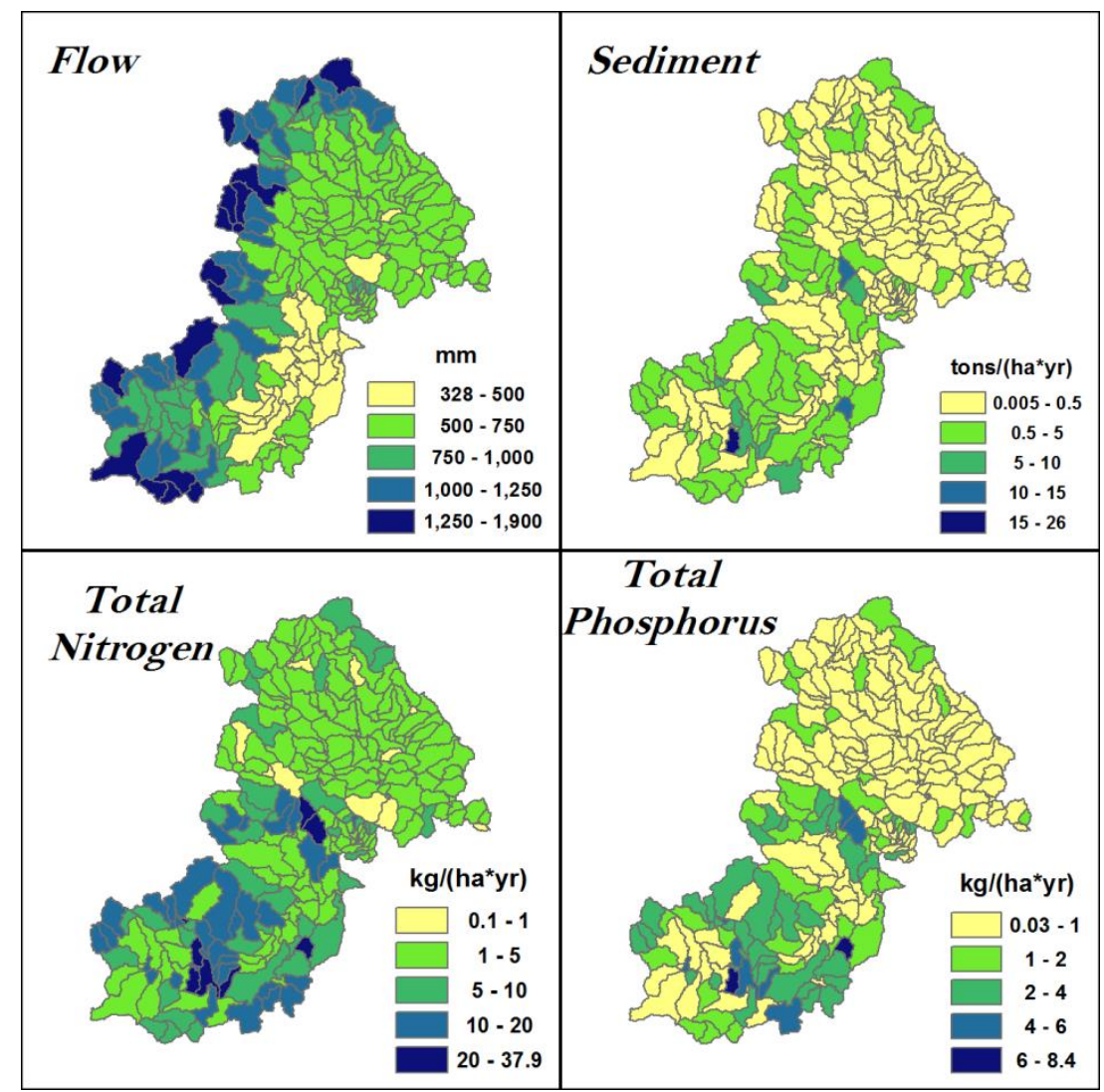

Figure 11: Spatial patterns of predicted flow, sediment, total nitrogen, and total phosphorus. 
There are intra- and inter-basin spatial patterns for sediment. Predicted terrestrial yields in the Tualatin are uniformly smaller than those in the Yamhill. This disparity is likely due to in-stream processes in the model not being properly calibrated. This type of calibration could be done in the future using a submerged jet to characterize the erosion taking place when stress is applied to the channel surface (Hanson 1990, Allen et al 1999). This is resource intensive, and results are likely to vary throughout the stream network based on particle size distribution (Kaufmann et al 2008). It should be noted that SWAT's default sediment routing algorithm, the simplified Bangold equation assumes all sediment is of silt size, and it does not partition erosion between the stream bank and stream bed. More advanced routines are available that does take into account particle size. However, it is still incumbent on the user to define the median particle diameter.

At the time of this writing, no field studies could be found detailing sediment yields off the landscape. A study using the EPIC model in the Tualatin exists (Moberg 1995), but no empirical data were used. Moberg (1995) recommends further field scale data collection, but no study has yet been completed. As a result of default in-stream sediment processes, higher in-stream sediment yields are apportioned directly to terrestrial erosion in this study.

Intra-basin variation is due to the combination of landscape factors such as land uses and slopes. In the Tualatin, modeling results indicate that the majority of erosion is due to clear-cuts located on high slopes throughout the Coast Range. Since cultivated agricultural lands are found more frequently on low to medium slopes in the Tualatin, 
there is less opportunity for severe erosion to take place. In the Yamhill, the most severe erosion comes from lands classified as hay which reside on steeper slopes. In both basins forested areas contribute least to erosion due to the soil's thick layers of humus and protection from rain splash erosion.

Much of the nutrient loads into streams travel either bound to colloids or in solution with overland flow, so sub-basins with higher sediment yields also see higher nitrogen and phosphorus yields. This explains the similar inter-basin patterns for TN and TP. While studies have shown a relatively higher phosphorous concentration in the Tualatin River due to naturally occurring concentrations of phosphorus in the Hillsboro Formation (Wilson et al 1999), the similar progeny of soils extant in both basins suggest this pattern is present in Yamhill as well (email correspondence with Scott Burns). Thus, the inter-basin differences in phosphorus are mainly due to its relationship with sediment.

\subsection{Future Changes and Adaptive Management}

While there are decreases in sediment and nutrients basin-wide under some scenarios, urban areas consistently show increases. This finding is consistent with many previous studies (Tong and Chen 2002, Franczyk and Chang 2009, Tu 2009, Praskievicz and Chang 2011), and emphasizes the need for adaptive policies addressing these pollution sources.

The wide range of responses to climate scenarios points to the uncertainty inherent in climate models, and the corresponding hydrological response to these 
changes. Non-linear effects such as summertime increases in flow despite summertime reductions in precipitation in the medium scenario highlight some unexpected changes that may take place. This wide variation stresses the need for managers to develop adaptive plans which incorporate these uncertainties while scientists work to develop climate models with less uncertainty.

This study demonstrates the ability of SWAT to locate CSAs, and visualize how they may change in the future. Due to this model's limitation in how it represents land cover, and a lack of research validating CSAs identified by SWAT (Niraula et al. 2013), more research is needed before these CSAs can be used to guide regulatory activities. The application of VFS clearly demonstrates the advantage of best management practices, whether the issue being addressed is urban growth, or agricultural runoff. This research suggests that VFS could be used as a method of promoting sustainable land management practices. 


\section{Conclusions}

Changes in precipitation levels and urban growth are two main drivers that threaten watershed health in the future. This study focusses on assessing hydrologic and water quality changes to precipitation and urban growth, and investigates how the application of vegetative filter strips might ameliorate these effects.

Flows typically follow precipitation trends, but some non-linear effects result from seasonal soil water storage permitting summer flows to increase despite reductions in summer rains. Urban areas show larger increases in flows due to high percentages of impervious surfaces. Winter flow changes are similar to annual changes.

As flow increases, sediment yields increase basin-wide in most scenarios. Urban areas display particular sensitivity to increases in sediment yields, possibly due to their historically small yields relative to other land uses. TN yields increase basin-wide in most scenarios. High sloping regions with hay and rangelands have the highest TN yields. Urban areas show the greatest sensitivity to future climate and land use change. TP yields increase in exactly half of the scenarios, however the percent increases in these scenarios is greater than the decreases. Spatial patterns follow those of sediment. The greatest increases can be seen in urban lands. These findings suggest that urban areas can be targeted for reducing high flows and additional nutrient and sediment loads.

CSAs are located in areas of high slopes and hay or range lands. CSAs shift under urban growth and climate change suggesting that managers could use models to identify areas deserving extra regulatory attention; however validation through field 
studies is required before model output can be trusted. Changes in CSAs appear to be related more to climate change than urban growth in this study. Implementation of VFS reduced sediment and nutrient loads to the stream suggesting this should be promoted as a best management practice for land owners.

The results of this study suggest that SWAT is a useful tool for identifying target areas for reducing nutrient and sediment loads and evaluating the effects of alternative land management on nutrient and sediment loads under the pressure of climate change and urban growth. Future studies should focus on validating CSAs identified by SWAT and characterizing downstream effects resulting from best management practices. 


\title{
7. References Cited
}

Abatzoglou, J.T. 2013. Development of gridded surface meteorological data for ecological applications and modeling. International Journal of Climatology 33:121-131.

\begin{abstract}
Abatzoglou, J.T., and Brown, T.J. 2012. A comparison of statistical downscaling methods suited for wildfire applications. International Journal of Climatology 32: 772780.
\end{abstract}

Abu-Zreig, M., Rudra, R.P., Whiteley, H.R., Lalonde, M.N., and Kaushik, N.K. 2003. Phosphorus removal in vegetated filter strips. Journal of Environmental Quality 32:613619.

Abu-Zreig, M., Rudra, R.P., Lalonde, M.N., Whiteley, H.R., and Kaushik, N.K. 2004. Experimental investigation of runoff reduction and sediment removal by vegetated filter strips. Hydrological Processes 18:2029-2037.

Allen, P.M, Arnold, J., Jakubowski, E. 1999. Prediction of stream channel erosion potential. Environmental and Engineering Geoscience 5:339-351. 
Arnold, J.G., Srinivasan, R., Muttiah, R.S., and Williams, J.R. 1998. Large area hydrologic modeling and assessment part I: Model Development. Journal of the American Water Resources Association 34(1):73-89.

Arnold, J.G., Moriasi, D.N., Gassman, P.W., Abbaspour, K.C., White, M.J., Srinivasan, R., Santhi, C., Harmel, R.D., van Griensven, A., Van Liew, M.W., Kannan, N., and Jha, M.K. 2012. SWAT: Model use, calibration, and validation. Transactions of the ASABE 55(4):1491-1508.

Atasoy, M., Palmquist, R.B., Phaneuf, D.J. 2006. Estimating the effects of urban residential development on water quality using microdata. Journal of Environmental Management 79:399-408.

Boeder, M., H. Chang. 2008. Multi-scale analysis of oxygen demand trend in an urbanizing Oregon watershed. Journal of Environmental Management 400(1-3): 567581.

Brown, L.C. and Barnwell Jr., T.O. 1987. The enhanced water quality models QUAL2E and QUAL3E-UNCAS documentation and user manual. EPA document EPA/600/387/007. USEPA, Athens, GA. 
Chang, H., Evans, B.M., and Easterling, D.R. 2001. The effects of climate change on stream flow and nutrient loading. Journal of the American Water Resources Association 37(4):973-985.

Chang, H. 2004. Water quality impacts of climate and land use changes in southeastern Pennsylvania. The Professional Geographer 56(2):240-257.

Chang, H., and Jung, I-W. 2010. Spatial and temporal changes in runoff caused by climate change in a complex large river basin in Oregon. Journal of Hydrology 388(34):186-207.

City of McMinville [Data]. (2011). http://www.ci.mcminnville.or.us/

CWS (Clean Water Services) [Data]. 2011. 16060 SW 85th Ave, Tigard, OR 97224.

Choi, W. 2008. Catchment-scale hydrological response to climate-land-use combined scenarios: A case study for the Kishwaukee River Basins, Illinois. Physical Geography 29(1):79-99.

Ferrari, R.L. 2001. Henry Hagg Lake 2001 Survey. Sedimentation and River Hydraulics Group. Denver, Co. 
Franczyk, J., and Chang, H. 2009. The effect of climate change and urbanization on the runoff of the Rock Creek basin in the Portland metropolitan area, Oregon, USA. Hydrological Processes 23:805-815.

Hanson, G.J. 1990. Surface erodibility of earthen channels at high stresses. Part IIDeveloping an in situ testing device. Transactions of ASAE 33:132-137.

Hoyer M. 2013. Scenario Development and Analysis of Freshwater Ecosystem Services under Land Cover and Climate Change in the Tualatin and Yamhill River Basins, Oregon. Master's thesis. Portland State University.

Hoyer M, Chang H. 2014. Development of future land cover change scenarios in the metropolitan fringe, Oregon, U.S.A. with a participatory element (in review).

Kaufmann, P.R., Faustini, J.M., Larsen, D.P., Shirazi, M.A. 2008. A roughness-corrected index of relative bed stability for regional stream surveys. Geomorphology 99:150-170.

MACA (Multivariate Adaptive Constructed Analogs) Statistical Downscaling Method [Data]. 2013. Data Retrieved from: http://nimbus.cos.uidaho.edu/MACA/

Meyer, J.L., Paul, M.J., and Taulbee, W.K. 2005. Stream ecosystem function in urbanizing landscapes. Journal of the North American Benthological Society 24(3):602612. 
Moberg, D. 1995. Tualatin basin farm effects on runoff quality. Part III: EPIC Model Predictions. USDA - Natural Resources Conservation Service.

Moriasi, DN, Arnold, J.G., Van Liew, M.W., Bingner, R.L., Harmel, R.D., Veith, T.L. 2007. Model evaluation guidelines for systematic quantification of accuracy in watershed simulations. Transactions of the ASABE 50(3):885-900.

Munoz-Carpena R., Parsons, J.E. 1999. Modeling hydrology and sediment transport in vegetative filter strips. Journal of Hydrology 214:111-129.

Neitsch, S.L., J.G. Arnold, J.R. Kiniry, J.R. Williams. 2011. Soil and Water Assessment Tool Theoretical Documentation Version 2009. Texas Water Resources Institute Technical Report No. 406.

NHD (National Hydrography Dataset) Plus (Version 1) [Data]. 2010. Retrieved from http://www.horizon-systems.com/nhdplus/

Niraula R., Kalin, L., Srivastava, P., Anderson, C.J. 2013. Identifying critical source areas of nonpoint source pollution with SWAT and GWLF. Ecological Modelling 268:123-133. 
Oregon Department of Environmental Quality (ODEQ) 2012 [Data]. Provided by Eugene Foster from LASAR Database: deq12.deq.state.or.us/lasar2/

Oregon Department of Environmental Quality (ODEQ) 2001. Tualatin Sub-basin Total maximum Daily Load (TMDL):

http://www.deq.state.or.us/wq/tmdls/docs/willamettebasin/tualatin/tmdlwqmp.pdf. Last accessed 3/1/2013.

Paul, M.J., and Meyer, J.L. 2001. Streams in the urban landscape. Annual Review of Ecology, Evolution, and Systematics 32:333-365.

Praskievicz, S., and Chang, H. 2011. Impacts of climate change and urban development on water resources in the Tualatin River Basin, Oregon. Annals of the Association of American Geographers 101(2):249-271.

Pratt, B., and Chang, H. 2012. Effects of land cover, topography, and built structure on seasonal water quality at multiple scales. Journal of Hazardous Materials 209/210:48-58.

Randall, G.W., and Mulla, D.J. 2001. Nitrate nitrogen in surface waters as influenced by climatic conditions and agricultural practices. Journal of Environmental Quality 30:337344. 
Runkel, R.L., Crawford, C.G., and Cohn, T.A. 2004. Soad Estimator (LOADEST): A FORTRAN program for estimating constituent loads in streams and rivers. In Techniques and Methods Book 4. USGS. Reston, VA.

Soil Conservation Service. 1972. Section 4: Hydrology In National Engineering Handbook. SCS.

STATSGO (State Soil Geographic) Database [Data]. 2010. Included in SWAT model download: http://swat.tamu.edu/

Sullivan, A.B., and Rounds. S.A. 2005. Modeling hydrodynamics, temperature, and water quality in Henry Hagg Lake, Oregon, 2000-03. U.S. Geological Survey Scientific Investigations Report 2004-526138 p.

Tang, Z., Engel, B.A., Pijanowski, B.C., Lim, K.J. 2005. Forcasting land use change and its environmental impact at a watershed scale. Journal of Environmental Management $76: 35-45$.

Tong, S.T.Y., and Chen, W. 2002. Modeling the relationship between land use and surface water quality. Journal of Environmental Management 66:377-393. 
Tu, J. 2009. Combined impact of climate and land use changes on streamflow and water quality in eastern Massachusetts, USA. Journal of Hydrology 379:268-283.

USGS (US Geological Survey). US Land cover. 2011. Retrieved from The USGS Land Cover Institute's website: http://landcover.usgs.gov/uslandcover.php.

USGS (US Geological Survey). National Water Information System (NWIS). 2012. http://waterdata.usgs.gov/nwis/

Vorosmarty, C.J., Green, P., Salisbury, J., and Lammers, R.B. 2000. Global water resources: Vulnerability from climate change and population growth. Science 289:284288.

Walch, C.J., Roy, A.H., Feminella, J.W., Cottingham, P.D., Groffman, P.M., and Morgan II, R.P. 2005. Journal of the North American Benthological Society 24(3):706-723.

White, M.J., and Arnold, J.G. 2009. Development of a simplistic vegetative filter strip model for sediment and nutrient retention at the field scale. Hydrological Processes 23:1602-1616. 
Whitehead, P.G., Wilby, R.L., Battarbee, R.W., Kernan, M., and Wade, A.J. 2009. A review of the potential impacts of climate change on surface water quality. Hydrological Sciences Journal 54(1):101-123.

Williams, J.R. 1975. Sediment-yield prediction with universal equation using runoff energy factor. P. 244-252. In Present and prospective technology for predicting sediment yield and sources: Proceedings of the sediment-yield workshop, USDA Sedimentation Lab., Oxford, MS, November 28-30, 1972. ARS-S-40.

Wilson, D.C., Burns, S.F., Jarrell, W., Lester, Alan, and Larson, E. 1999. Natural groundwater discharge of orthophosphate in the Tualatin Basin, Northwest Oregon. Environmental \& Engineering Geoscience 5(2):189-197. 


\section{Appendix A: Model Configuration}

The Tualatin is a complicated basin to model due to the high level of management taking place. Because of this, a significant amount of time was spent finding and formatting data for input into SWAT and devising ways to incorporate various features of the basin. One example of this is the Henry Hagg Lake Reservoir. In order to configure SWAT to include the reservoir, the automated sub-basin delineation based on the stream network had to be manually re-configured. This change can be seen in Figure A.1. The USGS gage along Scoggins Creek and the USGS gage along Sain Creek were used as points to demarcate upstream sub-basins from Hagg Lake.

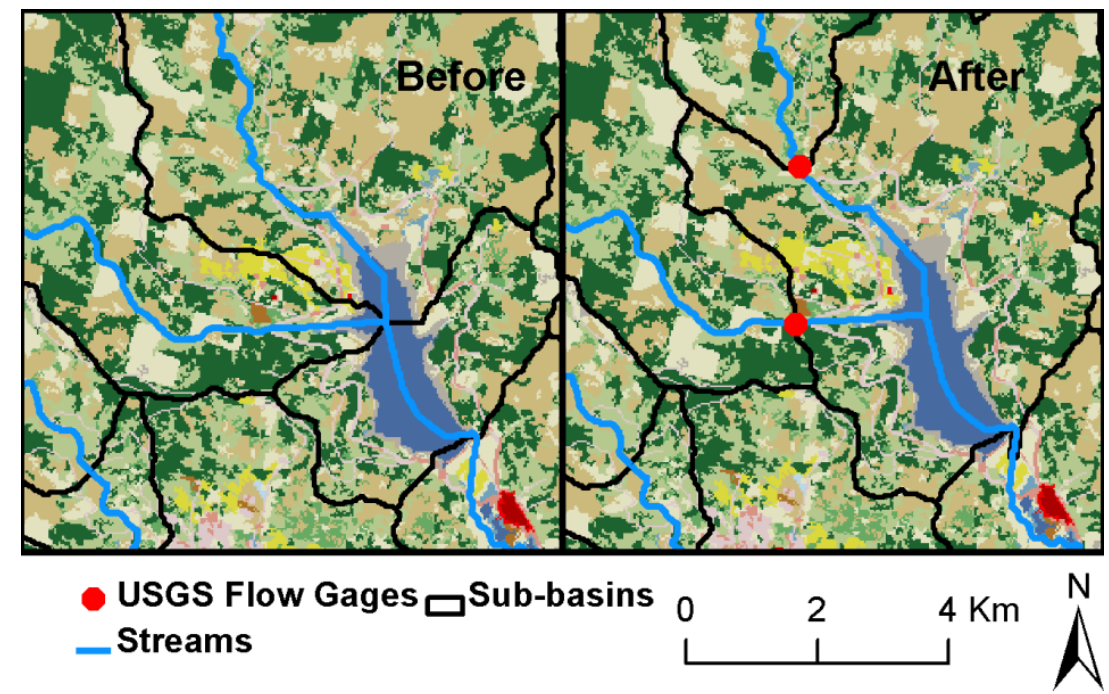

Figure A.1: Sub-basin delineation around Henry Hagg Lake had to be manually adjusted for a realistic representation of the spatial extent of the reservoir.

A second example is HRU definition. SWAT permits thresholds to be set to limit the size and complexity of the model. HRUs are composed of slope, soil, and land cover, and a threshold can be set for each. For example, if the land cover threshold is set to $20 \%$ and a sub-basin contains: 
10\% Cultivated Crops,

$30 \%$ Hay,

$25 \%$ Urban-Low density,

$15 \%$ Forest-Evergreen,

$10 \%$ Urban-Industrial,

10\% Urban-Medium density,

Hay, and Urban-Low density would be reapportioned so that

Hay $=(30 \% / 55 \%) * 100=54.55 \%$, and

Urban-Low density $=(25 \% / 55 \%) * 100=45.45 \%$.

SWAT documentation says "The threshold levels set for multiple HRUs is a function of the project goal and the amount of detail desired by the modeler. For most applications, the default settings for land use threshold (20\%) and soil threshold (10\%) and slope threshold (20\%) are adequate." (Winchell et al. 2010,pg. 131-132). For this thesis I used the default settings since future land cover scenarios had not yet been finalized during model construction. Since urban lands comprise small portions of the basin, these settings are problematic, as can be seen by the mostly similar outputs for both land covers. Furthermore, where changes in land cover are significant enough to reach the threshold, unusual changes in sub-basin level output can be seen as a result of a new land cover's inclusion in that sub-basin where it had been excluded previously. While these threshold levels are useful for simplifying the model and reducing run-time, given the scope of this research, a more moderate threshold should have been set for land 
cover and the additional option of exempting certain land covers from this threshold should have been applied to all urban lands. 


\section{Appendix B: Sensitivity Analysis, Calibration, and Validation}

Sensitivity Analysis was performed for many parameters in both the Tualatin and Yamhill basins. The SWAT-CUP software provides automated routines and graphical output which enables detailed inspection of a parameter's sensitivity (Abbaspour 2012). An example of parameter sensitivity for EPCO (Plant uptake compensation factor), can be seen in figure B.1. This parameter demonstrates slight changes to wintertime peaks, but is otherwise insensitive. Sensitivity analysis was done for 43 parameters.

Sensitivities for select parameters can be seen in Table B.1.

\section{EPCO Sensitivity Analysis}

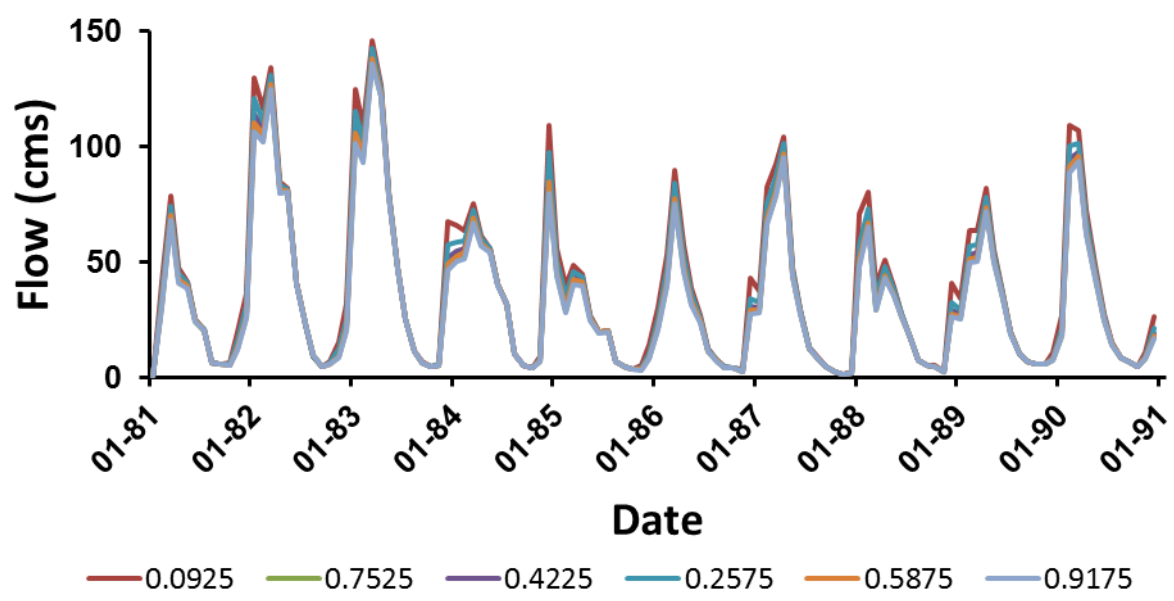

Figure B.1: Sensitivity analysis of the EPCO parameter. 
Table B.1: List of final calibrated parameters for Tualatin and Yamhill sub-basins

\begin{tabular}{|c|c|c|c|c|}
\hline Description & Parameter & Min & Max & $\begin{array}{l}\text { Sensitivity } \\
\text { ([I]ncrease, } \\
\text { [D]ecrease) }\end{array}$ \\
\hline \multicolumn{5}{|l|}{ Flow } \\
\hline $\begin{array}{l}\text { Baseflow alpha factor } \\
\text { (days) }\end{array}$ & v__ALPHA_BF.gw & 0 & 1 & $\begin{array}{l}\text { Wet season: I } \\
\text { Dry season: D }\end{array}$ \\
\hline $\begin{array}{l}\text { Soil evaporation } \\
\text { compensation factor }\end{array}$ & v__ESCO.bsn & 0.01 & 1 & I \\
\hline $\begin{array}{l}\text { Plant uptake } \\
\text { compensation factor }\end{array}$ & v__EPCO.bsn & 0 & 1 & $\mathrm{D}$ \\
\hline $\begin{array}{l}\text { Available water capacity } \\
\text { of the soil layer }\end{array}$ & r__SOL_AWC().sol & -0.2 & 0.2 & $\mathrm{D}$ \\
\hline $\begin{array}{l}\text { Treshold depth of water } \\
\text { in the shallow aquifer } \\
\text { required for return flow } \\
\text { to occur (mm) }\end{array}$ & v__GWQMN.gw & 0 & 5000 & $\mathrm{D}$ \\
\hline \multicolumn{5}{|l|}{ Sediment } \\
\hline Average slope length & r__SLSUBBSN.hru & 10 & 150 & I \\
\hline $\begin{array}{l}\text { Min value of USLE C } \\
\text { factor applicable to the } \\
\text { land cover/plant (Forest) }\end{array}$ & $\underset{\mathrm{t}}{\mathrm{r}} \mathrm{CUSLE \_ C.crop.da}$ & $\begin{array}{c}0.00 \\
1\end{array}$ & 0.5 & I \\
\hline $\begin{array}{l}\text { USLE equation soil } \\
\text { erodibility }(K) \text { factor }\end{array}$ & r__USLE_K().sol & 0 & 0.65 & I \\
\hline $\begin{array}{l}\text { Average Slope } \\
\text { Steepness }\end{array}$ & r_HRU_SLP.hru & 0 & 1 & I \\
\hline \multicolumn{5}{|l|}{ Nitrogen } \\
\hline $\begin{array}{l}\text { Nitrogen percolation } \\
\text { coefficient }\end{array}$ & v__NPERCO.bsn & 0.1 & 1 & I \\
\hline $\begin{array}{l}\text { Denitrification } \\
\text { exponential rate } \\
\text { coefficient }\end{array}$ & v__CDN.bsn & 0.1 & 3 & I \\
\hline $\begin{array}{l}\text { Denitrification threshold } \\
\text { water content }\end{array}$ & v__SDNCO.bsn & 0.1 & 1 & $\mathrm{D}$ \\
\hline
\end{tabular}

*v: Parameter is assigned this value. r: Parameter is multiplied by $1+$ this value.

LOADEST models had largely good model fit statistics. It should be noted, however, that these estimates were done using load rather than concentration, and thus suffer from spurious correlation since flow is used in both the independent and dependent 
variables (Shivers and Moglen 2008). A summary of LOADEST model results can be seen in Table B.2.

Table B.2: LOADEST sediment and nutrient results.

\begin{tabular}{|c|c|c|c|c|c|c|}
\hline Parameter & $\begin{array}{c}\text { Calibration } \\
\text { Period }\end{array}$ & $\begin{array}{c}\text { Grab } \\
\text { Samples }\end{array}$ & $\begin{array}{c}\text { Estimation } \\
\text { Period }\end{array}$ & NSE & PBIAS & $\mathbf{R}^{2}$ \\
\hline \multicolumn{7}{|c|}{ Tualatin River at West Linn } \\
\hline$T S S$ & $1988-2010$ & 828 & $1981-2010$ & 0.06 & 11.14 & 0.94 \\
\hline$T N$ & $1974-2002$ & 545 & $1981-2010$ & 0.93 & 0.12 & 0.95 \\
\hline $\boldsymbol{T P}$ & $1974-2010$ & 972 & $1981-2010$ & 0.65 & 5.63 & 0.92 \\
\hline \multicolumn{7}{|c|}{ Tualatin River at Dilley } \\
\hline$T S S$ & $1984-2011$ & 1014 & $1981-2010$ & 0.45 & -10.24 & 0.89 \\
\hline$T N$ & $1984-2011$ & 1,007 & $1981-2010$ & 0.68 & 3.15 & 0.88 \\
\hline$T P$ & $1984-2011$ & $1,032 *$ & $1981-2010$ & 0.67 & -2.80 & 0.84 \\
\hline \multicolumn{7}{|c|}{ Fanno Creek at Durham } \\
\hline$T S S$ & $\begin{array}{c}10 / 1 / 1993- \\
2012\end{array}$ & 530 & $\begin{array}{c}10 / 1 / 1993- \\
2010\end{array}$ & -1.76 & $46.09 \dagger$ & 0.93 \\
\hline$T N$ & $\begin{array}{c}10 / 1 / 1993- \\
2012\end{array}$ & $623 * *$ & $\begin{array}{c}10 / 1 / 1993- \\
2010\end{array}$ & 0.93 & 2.72 & 0.98 \\
\hline$T P$ & $\begin{array}{c}10 / 1 / 1993- \\
2012\end{array}$ & 733 & $\begin{array}{c}10 / 1 / 1993- \\
2010\end{array}$ & 0.66 & 1.75 & 0.98 \\
\hline \multicolumn{7}{|c|}{ Yamhill Water Quality Station } \\
\hline$T S S$ & $\begin{array}{c}10 / 1 / 1994- \\
2012\end{array}$ & 164 & $\begin{array}{c}10 / 1 / 1994- \\
2010\end{array}$ & 0.72 & 3.58 & 0.96 \\
\hline$T N$ & $\begin{array}{c}10 / 1 / 1994- \\
2007\end{array}$ & 132 & $\begin{array}{c}10 / 1 / 1994- \\
2010\end{array}$ & 0.77 & 8.86 & 0.97 \\
\hline$T P$ & $\begin{array}{c}10 / 1 / 1994- \\
2012\end{array}$ & 164 & $\begin{array}{c}10 / 1 / 1994- \\
2010\end{array}$ & 0.85 & -1.74 & 0.97 \\
\hline $\begin{array}{l}* 25 \text { samp } \\
\text { hardware de } \\
* * \quad 1 \text { sample }\end{array}$ & $\begin{array}{l}\text { registered be } \\
\text { tion limits } \\
\text { gistered belo }\end{array}$ & & $\begin{array}{l}\dagger \text { LOADEST } \\
\text { using models } \\
\text { than } 25 \%\end{array}$ & $\begin{array}{l}\text { loes } 1 \\
\text { ith } \mathrm{P}\end{array}$ & $\begin{array}{l}\text { t recomm } \\
\text { IAS great }\end{array}$ & \\
\hline
\end{tabular}

hardware detection limits

SWAT model fit was measured using both statistical and visual inspection.

Visual demonstration of model fit was not able to be included in the main document due 
to space constraints, so they are provided here in Figure B.2. While model fit is generally good, the model at times underestimates nutrient loads. Whether these disparities are due to inaccurate LOADEST estimates, or model construction is difficult to say. 

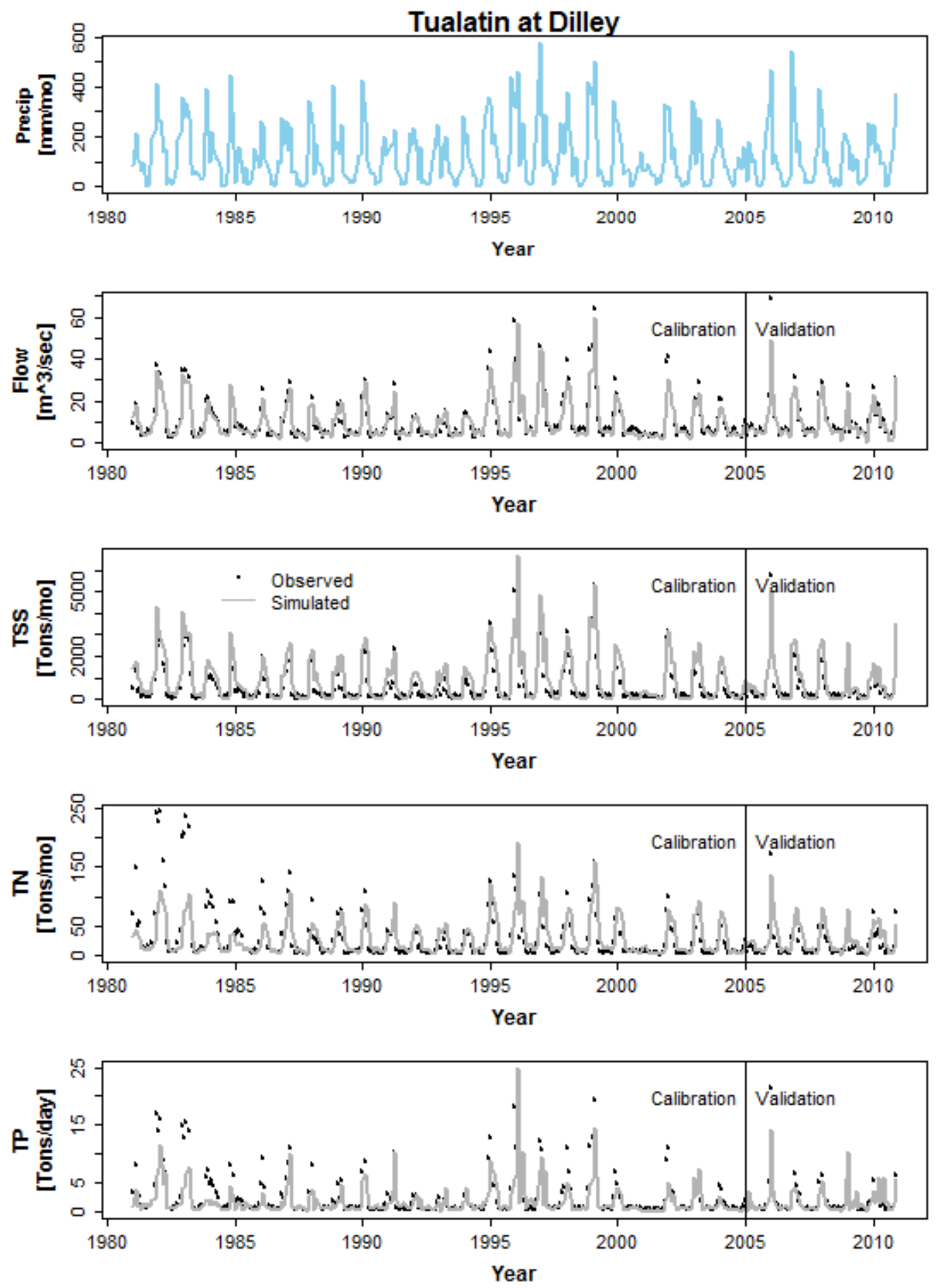

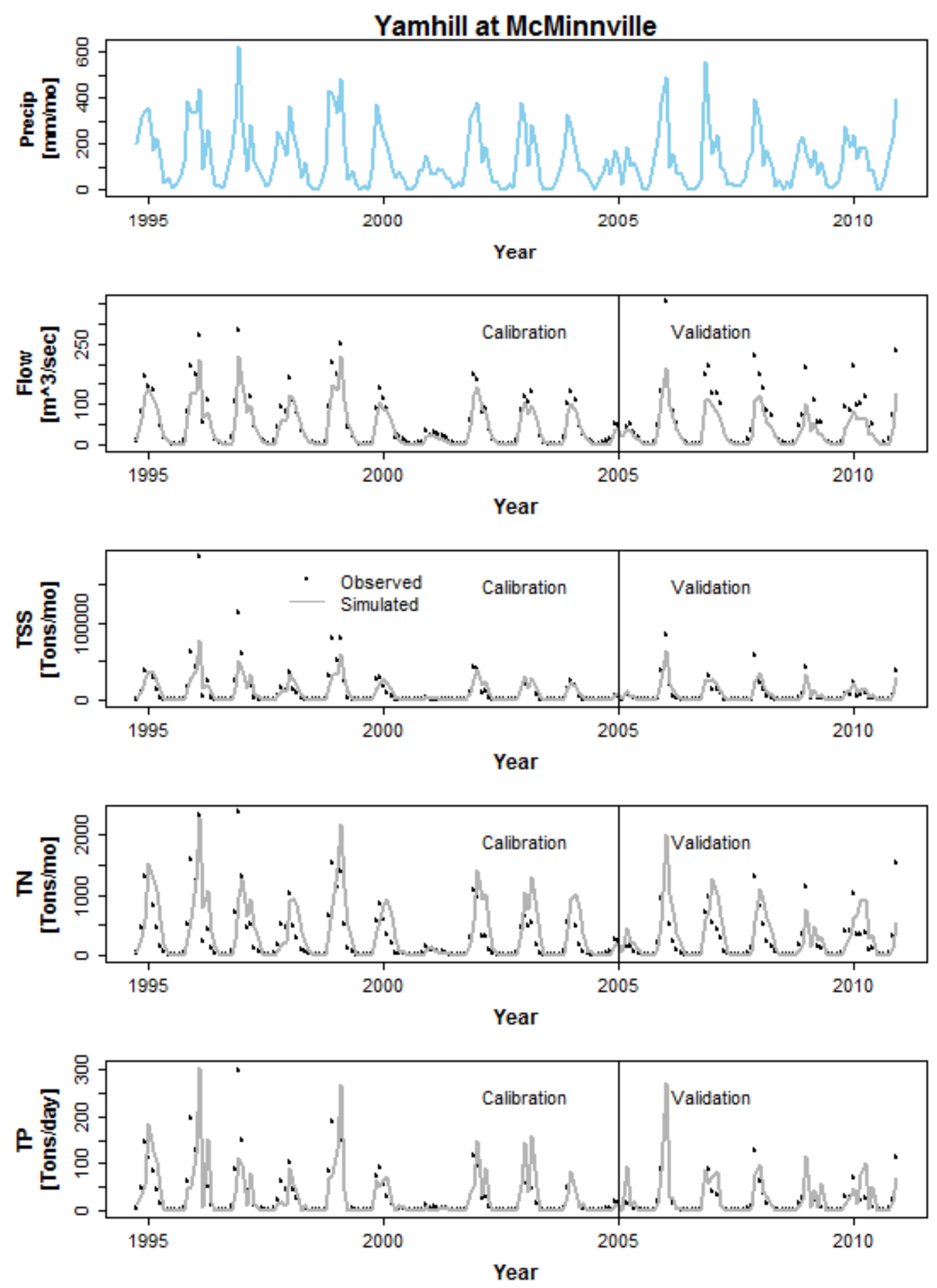

Figure B.2: Time series of calibrated and validated results for both the Tualatin and Yamhill sub-basins. 


\section{Appendix C: Uncertainty}

A formal uncertainty analysis was not conducted for this study, so what follows is a brief discussion of the various sources of uncertainty. The uncertainty in watershed modeling can be categorized into 3 types. Measurement uncertainty derives from the uncertainty inherent in the field collected "observed" data used to calibrate a model. Measurement uncertainty can be estimated using the detection limits of the hardware used to make field observations. In our study the USGS and DEQ flow, sediment and nutrient data fall under this category. The LOADEST model estimates also fall under this category.

The second type is model uncertainty and derives from the fact that no model incorporates all physical processes, nor are all physical processes known to us. An example of this kind of uncertainty is the "second storm" effect, where sediment and nutrients are flushed through the system by a rain storm, so that concentrations in a follow up storm are over-estimated.

The third type is parameter uncertainty and derives from the spatial and temporal variation in parameters used to calibrate the model. Many parameters are difficult to measure empirically, and so the inverse modeling technique is used to estimate the value of these parameters (Abbaspour et al. 1999). However, the non-uniqueness, or equifinality problem, where different combinations of parameters can result in the same model output prevent a clear method for acquiring the true parameter values (Abbaspour 2012). Parameter uncertainty can be estimated by measuring the model response to various parameter inputs. This analysis is computationally intensive and requires over 
500 model runs. It also requires the modeler to select realistic parameter ranges, a figure which may change depending on the experience level of the modeler, and the modeler's familiarity with the study site. 


\section{Appendix D: Historic and Future Climate}

Historic summaries of climate in the two basins based off of data provided by Abatzoglou (2013) had to be removed from the main document but can be seen in Figure D.1. Spatial distribution of the gridded future climate scenarios for annual and seasonal scales can be seen in Figure D.2.

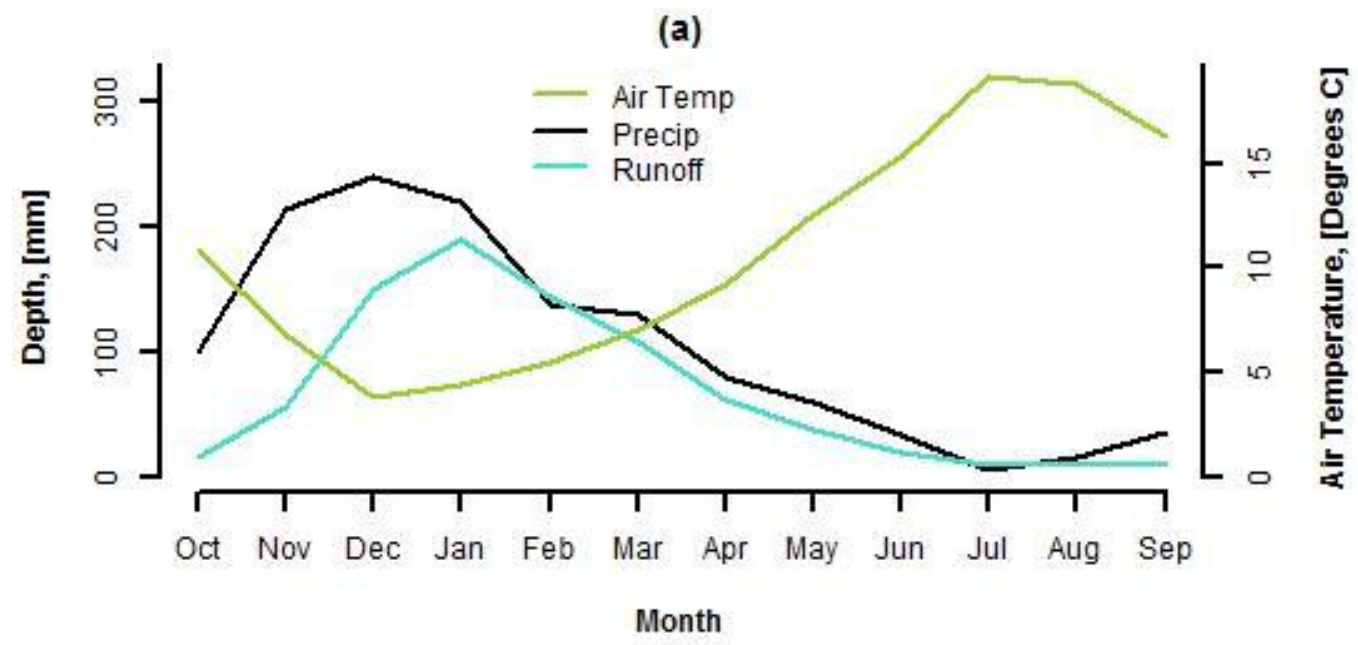

(b)

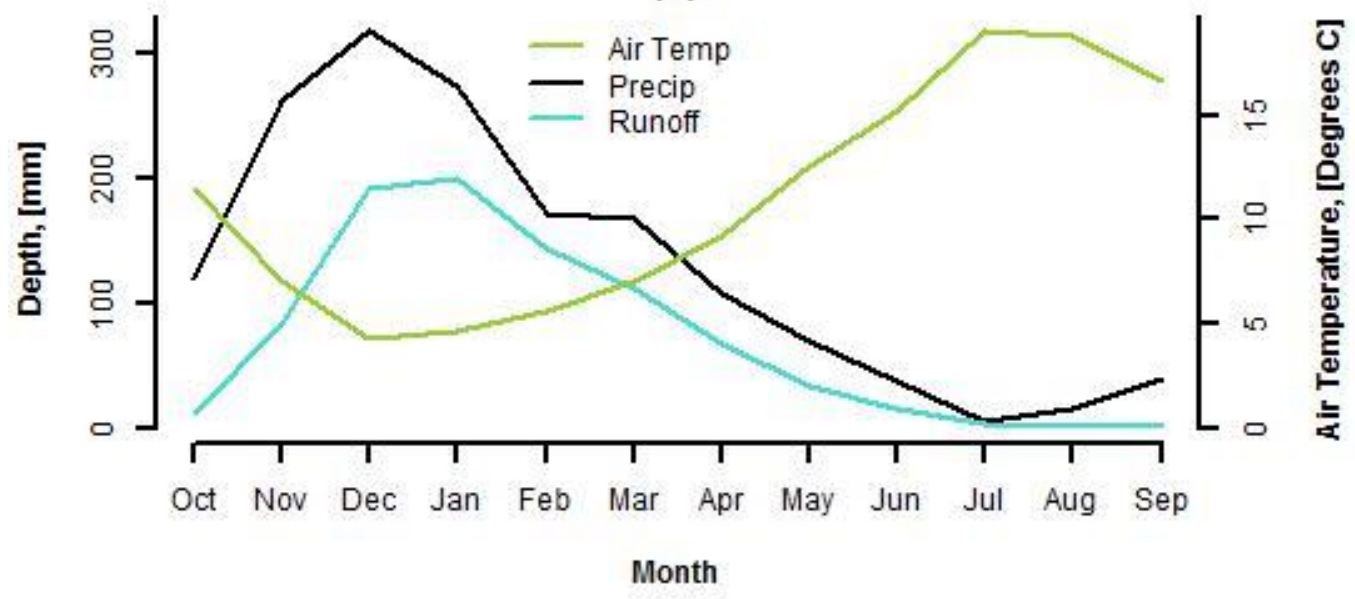

Figure D1: Hydroclimate in the (a) Tualatin and (b) Yamhill sub-basins, 1995-2010 Water year 

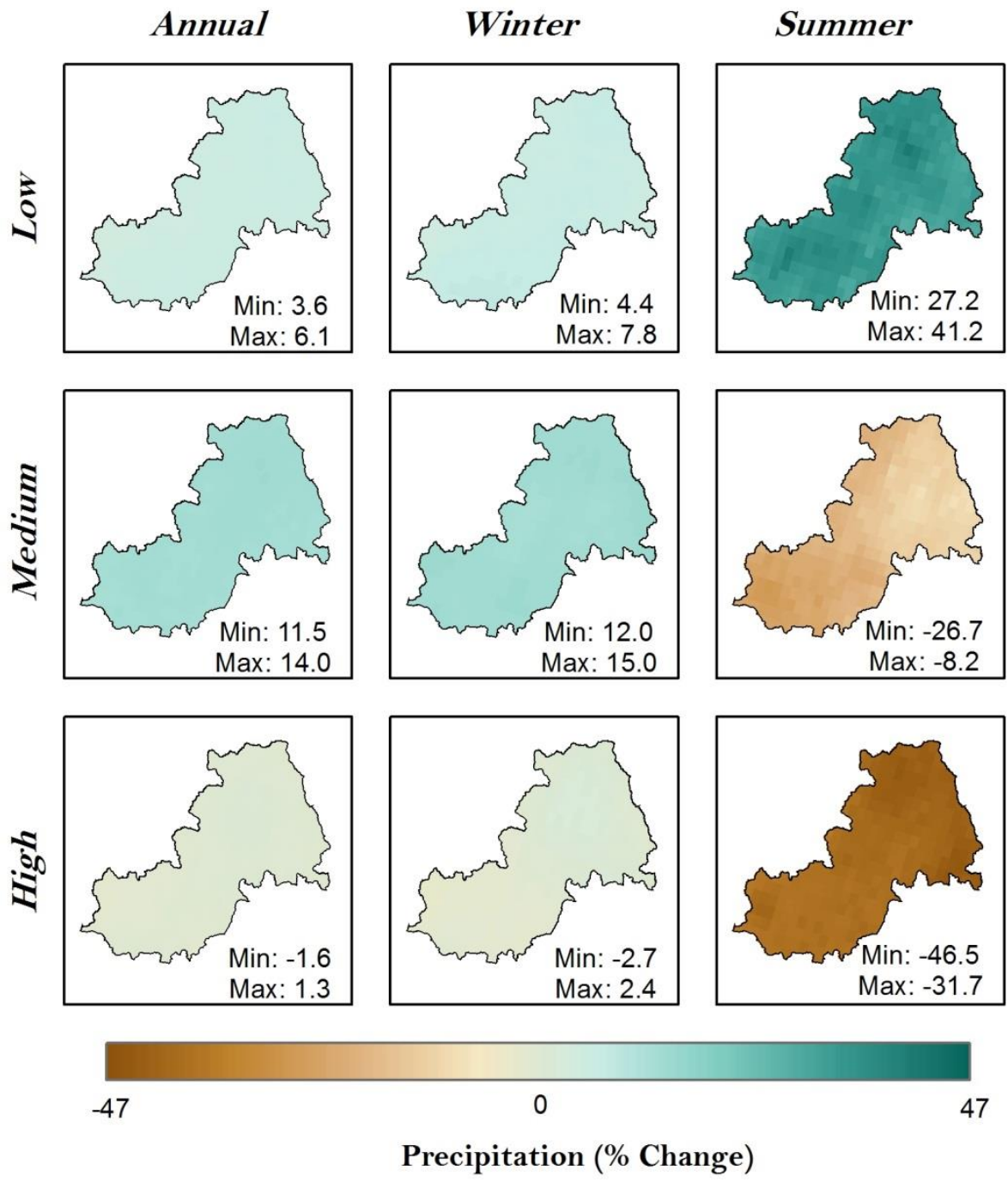

Figure D.2: Spatial distribution of annual and seasonal changes to precipitation in each of the three climate scenarios.

\section{References Cited}

Abatzoglou, J.T. 2013. Development of gridded surface meteorological data for ecological applications and modeling. International Journal of Climatology 33:121-131. 
Abbaspour, K.C., Sonnleitner, M.A., Schulin, R. 1999. Uncertainty in estimation of soil hydraulic parameters by inverse modeling: Example lysimeter experiments. Soil Science Society of America Journal 63:501-509.

Abbaspour, K.C. 2012. SWAT-CUP 2012: SWAT Calibration and uncertainty programs - A user manual. EAWAG.

Shivers, D.E., and Moglen, G.E. 2008. Spurious correlation in the USEPA rating curve method for estimating pollutant loads. Journal of Environmental Engineering 134:610618.

Winchell, M., Srinivasan, R., Di Luzio, M., Arnold, J. 2010. ArcSWAT Interface for SWAT 2009 User's Guide. Blackland Research Center. Temple, Texas. 